\title{
Phosphorylation of Coat Protein by Protein Kinase CK2 Regulates Cell-to-Cell Movement of Bamboo mosaic virus Through Modulating RNA Binding
}

\author{
Chien-Jen Hung, ${ }^{1}$ Ying-Wen Huang, ${ }^{1}$ Ming-Ru Liou, ${ }^{1}$ Ya-Chien Lee, ${ }^{1}$ Na-Sheng Lin, ${ }^{1,2}$ Menghsiao Meng, ${ }^{1}$ \\ Ching-Hsiu Tsai, ${ }^{1}$ Chung-Chi Hu, ${ }^{1}$ and Yau-Heiu Hsu ${ }^{1}$ \\ ${ }^{1}$ Graduate Institute of Biotechnology, National Chung Hsing University, Taichung 40227, Taiwan; ${ }^{2}$ Institute of Plant and \\ Microbial Biology, Academia Sinica, Taipei 11529, Taiwan
}

Submitted 17 April 2014. Accepted 9 July 2014.

In this study, we investigated the fine regulation of cell-tocell movement of Bamboo mosaic virus (BaMV). We report that the coat protein (CP) of BaMV is phosphorylated in planta at position serine 241 (S241), in a process involving Nicotiana benthamiana casein kinase $2 \alpha(\mathrm{NbCK} 2 \alpha)$. BaMV $\mathrm{CP}$ and $\mathrm{NbCK} 2 \alpha$ colocalize at the plasmodesmata, suggesting that phosphorylation of BaMV may be involved in its movement. S241 was mutated to examine the effects of temporal and spatial dysregulation of phosphorylation on i) the interactions between $C P$ and viral RNA and ii) the regulation of cell-to-cell movement. Replacement of S241 with alanine did not affect RNA binding affinity but moderately impaired cell-to-cell movement. A negative charge at position 241 reduced the ability of CP to bind RNA and severely interfered with cell-to-cell movement. Deletion of residues 240 to 242 increased the affinity of $C P$ to viral RNA and dramatically impaired cell-to-cell movement. A threonine at position 241 changed the binding preference of CP toward genomic RNA and inhibited cell-to-cell movement. Together, these results reveal a fine regulatory mechanism for the cell-to-cell movement of BaMV, which involves the modulation of RNA binding affinity through appropriate phosphorylation of CP by NbCK $2 \alpha$.

Post-translational modifications (PTM) serve to regulate and expand the functions of proteins (Prabakaran et al. 2012). For viruses with relatively small genomes, PTM are often involved in modulating the structures and functions of viral proteins (Alcaide-Loridan and Jupin 2012; Barajas and Nagy 2010; Mathur et al. 2012; Perez Jde et al. 2013; Samuilova et al. 2013; Xiong and Wang 2013). One of the most extensively studied PTM is reversible phosphorylation, which has been implicated in various processes of virus infection cycles in host cells (Bond et al. 2011; Jakubiec and Jupin 2007). Phosphorylation of plant viral proteins has been reported to modulate interactions between proteins or viral RNAs (vRNAs) (Samuilova et al. 2013; Shapka et al. 2005; Stork et al. 2005;

Corresponding authors: Y.-H. Hsu; E-mail: yhhsu@dragon.nchu.edu.tw; and C.-C. Hu; E-mail: cchu@ dragon.nchu.edu.tw

* The $\boldsymbol{e}$-Xtra logo stands for "electronic extra" and indicates that two supplementary tables and one supplementary figure are published online and that Figures 7 and 9 appear in color online.

(C) 2014 The American Phytopathological Society
Vijayapalani et al. 2012; Zayakina et al. 2008), infection and symptom development (Champagne et al. 2007; Chapdelaine et al. 2002; Chowda-Reddy et al. 2008; Florentino et al. 2006; Ivanov et al. 2003; Jakubiec et al. 2006; Kleinow et al. 2009; Lewsey et al. 2009), and subcellular localizations (Kawakami et al. 1999, 2003; Link et al. 2011).

In addition to replication, viruses need to be able to undergo cell-to-cell and systemic movement in order to complete their infection cycle. Plant viruses encode movement proteins (MP), which play key roles in the movement of viruses into neighboring cells through plasmodesmata (PD) (Lucas 2006). However, the molecular mechanisms that regulate the binding and release of vRNAs by MP before and after passage through PD remain poorly understood. Accumulating evidence indicates that phosphorylation of viral MP is required for their functions (Lee and Lucas 2001). For example, the Tobacco mosaic virus (TMV) 30K MP has been shown to be phosphorylated (Citovsky et al. 1993; Haley et al. 1995; Karpova et al. 1999), and the extent of its phosphorylation modulates MP-PD interactions to regulate the gating function of MP and viral cell-tocell movement (Karger et al. 2003; Trutnyeva et al. 2005; Waigmann et al. 2000). Site-specific phosphorylation of MP also influences PD targeting and movement of Potato leaf roll virus (PLRV) (Link et al. 2011). The intracellular localization and stability of Tomato mosaic virus (ToMV) MP are also known to be regulated by phosphorylation (Kawakami et al. 1999, 2003). In the case of viruses that encode triple gene block proteins (TGBps) as MP, it has been shown that phosphorylation of TGBp3 of Potato mop top virus (PMTV) controls its interaction with TGBp2 and, hence, regulates viral cell-tocell movement (Samuilova et al. 2013).

In addition to MP, viral coat proteins (CP) and their PTM are also involved in the movement and infection processes for certain viruses. The $\mathrm{CP}$ of Cauliflower mosaic virus (CaMV) has been shown to be phosphorylated by the casein kinase II (CK2) of host plants, and mutations of CK2 phosphorylation sites abolish viral infectivity (Chapdelaine et al. 2002). Phosphorylation of CP of Potato virus A (PVA), a Potyvirus sp., has been shown to modulate its RNA-binding ability, and the prevention of its phosphorylation disrupted cell-to-cell and long distance movement of PVA (Ivanov et al. 2001, 2003). In Potato virus $X$ (PVX), the type species of the genus Potexvirus, in vitro phosphorylation of $\mathrm{CP}$ converts the encapsidated vRNA from a nontranslatable into a translatable form (Atabekov et al. 2001). However, for viruses that require both MP and CP for efficient cell-to-cell movement, such as viruses in the genus Potexvirus (Lucas 2006; Verchot-Lubicz 2005; Verchot-Lubicz 
et al. 2010), it is less well understood whether PTM of CP are also involved in the regulation of viral movement.

Bamboo mosaic virus (BaMV) is a member of the genus Potexvirus; it possesses a single-stranded positive-sense RNA genome, encapsidated in a flexuous virion of approximately $500 \mathrm{~nm}$ in length (Lin et al. 1977). The BaMV genome is $5^{\prime}$ capped and $3^{\prime}$-polyadenylated, and is 6,366 nucleotides (nt) in length, excluding the poly(A) tail, which encodes five open reading frames (ORFs) (Lin et al. 1992, 1994; Yang et al. 1997). Like all potexviruses, BaMV encodes three TGBps, TGBp1 through TGBp3, with molecular weights of 28, 13, and $6 \mathrm{kDa}$, respectively, and a $\mathrm{CP}$ of $25 \mathrm{kDa}$, all of which are required for efficient cell-to-cell movement (Lin et al. 2004, 2006; Tseng et al. 2009). In addition to viral genomic RNAs, two major subgenomic RNAs of approximately $2.0 \mathrm{~kb}$ (for the expression of TGBp1) and $1.0 \mathrm{~kb}$ (for the expression of $\mathrm{CP}$ ) could be detected in BaMV-infected plants and protoplasts (Lin et al. 1992, 1996). The accumulations of BaMV genomic and subgenomic RNAs have been found to be differentially affected by CP (Hung et al. 2014). We have previously shown that phosphorylation of the $\mathrm{P} 20$ protein encoded by the satellite RNA associated with BaMV (satBaMV RNA) converts translation-incompetent satBaMV RNA into a translatable form and delays systemic movement of satBaMV in Nicotiana benthamiana (Vijayapalani et al. 2012). This discovery prompted us to further investigate whether phosphorylation is involved in the regulation of movement by BaMV-encoded proteins.

In this study, we present the first evidence that the serine at position 241 (S241) of BaMV CP is phosphorylated in plant cells. In vitro phosphorylation assays revealed that S241 can be phosphorylated by CK2, an enzyme which is known to be present in several subcellular locations, including the plasma membrane (Faust and Montenarh 2000; Litchfield 2003; Rodriguez et al. 2005; Salinas et al. 2006). Mutations which

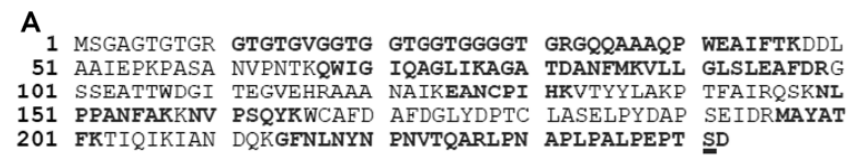

B ${ }_{227}$ LPNAPLPALPEPTPSD $_{242}$

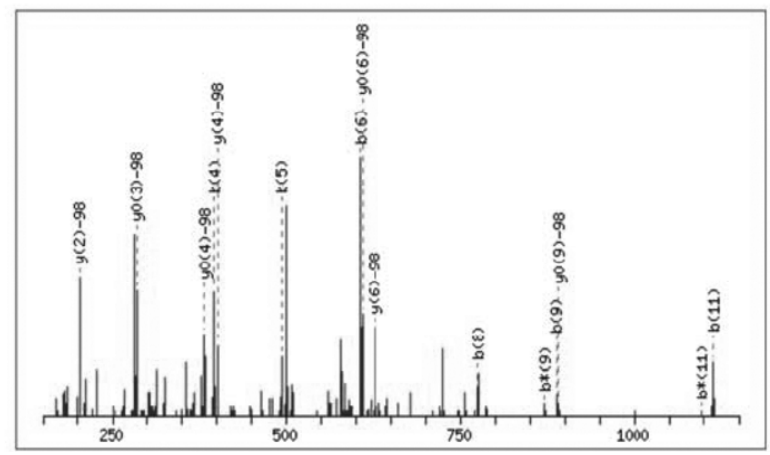

Fig. 1. Coat protein (CP) of Bamboo mosaic virus (BaMV) is phosphorylated at serine 241 (S241) in planta. BaMV virions were purified from infected Nicotiana benthamiana, and the CP were analyzed by liquid chromatography tandem mass spectrometry (LC/MS/MS). A, Amino acid sequence of BaMV CP. The peptide fragments identified by LC/MS/MS are shown in bold, with the phosphorylated amino acid (S241) underlined. B, Mass spectrum of the phosphorylated peptides. CP peptides from purified virions were analyzed using a QStar MS/MS spectrometer. Escherichia coli-expressed BaMV CP was used as a nonphosphorylated control. The ion spectrum corresponds to the peptide encompassing amino acid residues 227 to 242 ( ${ }_{227}$ LPNAPLPALPEPTpSD $_{242}$ ) with phosphorylated S241 and a $\mathrm{m} / \mathrm{z}$ value of 806.51 , as shown at the top. Both the $y$ - and b-type fragment ions are present in the mass spectrum. prevent or mimic phosphorylation increased or decreased the RNA-binding ability of BaMV CP, respectively, but both mutations hampered cell-to-cell movement. These results suggest that proper phosphorylation of BaMV $\mathrm{CP}$ may be involved in the regulation of viral cell-to-cell movement, through facilitating the release of vRNA from the ribonucleoprotein (RNP) complex, which consists of TGBps, CP, and BaMV RNA, following passage through PD.

\section{RESULTS}

The BaMV CP is phosphorylated at $\mathrm{S} 241$ in planta.

To analyze the phosphorylation status of BaMV CP in its native environment, BaMV virions were purified from infected $N$. benthamiana and subjected to analysis by liquid chromatography-tandem mass spectrometry (LC/MS/MS). The results covered over $53 \%$ of the BaMV CP amino acid sequence (Fig. 1A). A mono-phosphorylated peptide was detected, with the sequence ${ }_{227}$ LPNAPLPALPEPTpSD $_{242}$. MS/MS analysis of this peptide revealed a peak at $\mathrm{m} / \mathrm{z} 806.51246$, which corresponds to the precursor ion with a neutral loss of phosphoric acid (Fig. 1B). Based on the observed masses of fragment ions y2 and $y 3$ (Fig. 1B), it was determined that the phosphate group is positioned at the $\mathrm{S} 241$ residue.

\section{Phosphorylation of CP at S241 by CK2 $\alpha$ of $N$. benthamiana.}

To identify the kinase candidate contributing to the phosphorylation at S241 of BaMV CP, the software NetPhosK (Blom et al. 2004) provided by the Center for Biological Sequence Analysis was used. The result predicted that the phosphorylation site at $\mathrm{S} 241$ could be recognized by CK2. BaMV $\mathrm{CP}$ contains the $\mathrm{CK} 2$ phosphorylation motif, $[\mathrm{S} / \mathrm{T}] \mathrm{XX}[\mathrm{D} / \mathrm{E}]$ (Meggio and Pinna 2003) at Thr-106, Thr-111, Thr-179, Thr240, and S241. In silico data mining of the $N$. benthamiana draft genome (Bombarely et al. 2011) was used to identify the CK2 $\alpha$ gene from assembled expressed sequence tag sequences (Supplementary Fig. S1A). The predicted amino acid sequence of the $N$. benthamiana $C K 2 \alpha(N b C K 2 \alpha)$ gene shares high similarity with the orthologs from other species, as shown in the multiple alignment. The sequence identity between CK $2 \alpha$ orthologs was the highest for $N$. benthamiana and $N$. tabacum at $98 \%$ (Supplementary Table S1).

Recombinant NbCK2 $\alpha$ enzyme was expressed in Escherichia coli by amplifying the full-length $\mathrm{NbCK} 2 \alpha$ gene from $N$. benthamiana cDNA and cloning it in frame with the GST fusion tag in the pGEX4T1 expression vector. The GSTbCK $2 \alpha$ fusion protein was successfully expressed in a soluble form, and purified by sequential chromatography through glutathione resin and heparin columns (Fig. 2A). The enzyme activity of purified GST-bCK2 $\alpha$ was verified in the presence of $\left[\gamma^{32} \mathrm{P}\right]$-ATP using the well-known substrate casein (Allende and Allende 1995), which was efficiently phosphorylated (Fig. $2 \mathrm{~B}$, lane 3 ). The phosphorylation reaction was inhibited by the addition of $1 \mu \mathrm{g} / \mathrm{ml}$ heparin, a specific inhibitor of CK2 (Fig. $2 \mathrm{~B}$, lane 4). The presence of $500 \mu \mathrm{M}$ cold GTP efficiently reduced the signal by competing with $\left[\gamma^{32} \mathrm{P}\right]$-ATP (Fig. 2B, lane 5 ), in accordance with the unique ability of CK2 to use both ATP and GTP as phosphoryl donors (Allende and Allende 1995; Hathaway et al. 1980; Modena et al. 2008). In contrast, very low amounts of radiolabeled products were detected in the negative controls (Fig. 2B, lanes 1 and 2). These results demonstrate that purified GST-bCK2 $\alpha$ retains authentic CK2 enzyme activity. Thus, GST-bCK $2 \alpha$ was used in the following in vitro phosphorylation experiments. The effects of CP phosphorylation were investigated using the following mutants: S241D or S241E (in which S241 was replaced with aspartate [D] or glutamate [E], respectively) to mimic phosphorylation 
(Dean and Koshland 1990); S241A or $\Delta_{240} \mathrm{TSD}_{242}$ (in which S241 was replaced with alanine [A] or the phosphorylation site [T240 to D242] was deleted, respectively) to inhibit phosphorylation; and S241T (in which S241 was replaced with threonine $[\mathrm{T}])$ to alternate the $\mathrm{CK} 2 \alpha$ phosphorylation site. The wild-type (WT) and mutant CP were overexpressed in E. coli and purified as soluble proteins by sequential chromatography on phenyl, DEAE, and Superdex 200 columns. A representative result depicting the purification process of $\mathrm{WT} C \mathrm{CP}$ is shown in Figure 2C. The purified WT and mutant BaMV CP (Fig. 2D) were subjected to an in vitro kinase assay using recombinant GST-bCK2 $\alpha$ kinase in the presence of $\left[\gamma_{-}{ }^{32} \mathrm{P}\right]$ GTP. The results confirmed that both WT and S241T CP were extensively phosphorylated (Fig. 2E, lanes 1 and 5), whereas mutants lacking the phosphorylation site were not (Fig. 2E, lanes 2 and 6). Therefore, $\mathrm{CK} 2 \alpha$ may phosphorylate BaMV CP at $\mathrm{S} 241$.

\section{Subcellular colocalization of $\mathrm{CP}$ and NbCK2 $\alpha$.}

To test whether BaMV CP directly interacts with NbCK $2 \alpha$ in plants, in vivo bimolecular fluorescence complementation
(BiFC) assays (Citovsky et al. 2006) were performed, in which enhanced fluorescent protein (EYFP) was split into N-terminal (nEYFP) and C-terminal (cEYFP) fragments. In order to reduce the size of $\mathrm{CP}$ fused to $\mathrm{nEYFP}$ or $\mathrm{cEYFP}$, we used a truncated BaMV CP, in which the first 35 amino acids of the $\mathrm{N}$ terminus were deleted (Lan et al. 2010; Yang et al. 2007). As a positive control, nEYFP-CP and cEYFP-CP were transiently coexpressed in $N$. benthamiana, and intense fluorescence was observed in epidermal cells at 2 days postinoculation (dpi) (Fig. 3A), due to the interactions between BaMV CP. Bright yellow fluorescence was also observed when $N$. benthamiana leaves were co-infiltrated with nEYFP-CP and CEYFP-CK2 or nEYFP-CK2 and cEYFP-CP (Fig. 3B and C), suggesting that BaMV CP and CK2 $\alpha$ can, indeed, interact with each other in infected $N$. benthamiana cells. In contrast, no fluorescence signals were observed in $N$. benthamiana cells co-infiltrated with nEYFP and cEYFP (Fig. 3D). Closer examination revealed EYFP fluorescence at punctate structures (Fig. 3B and C), localized at positions similar to those of PD. To determine whether these interactions do occur at PD, we monitored subcellular localization by fusing the single transmembrane domain

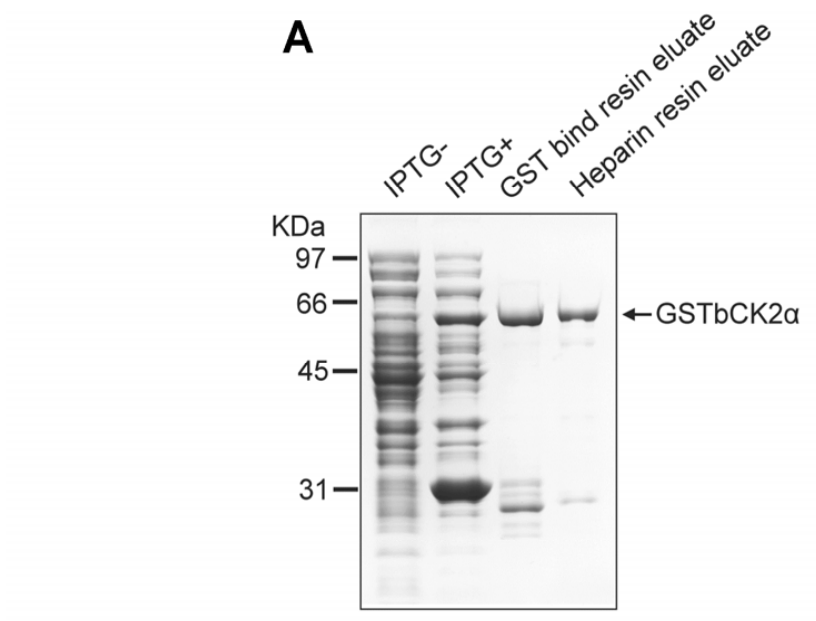

\section{B GSTbCK2 $\alpha+-+++$ casein - ++++

$\begin{array}{rlllll}1 \mu \mathrm{g} / \mathrm{ml} \text { Heparin } & - & - & - & + & - \\ 500 \mu \mathrm{M} \text { GTP } & - & - & - & - & +\end{array}$
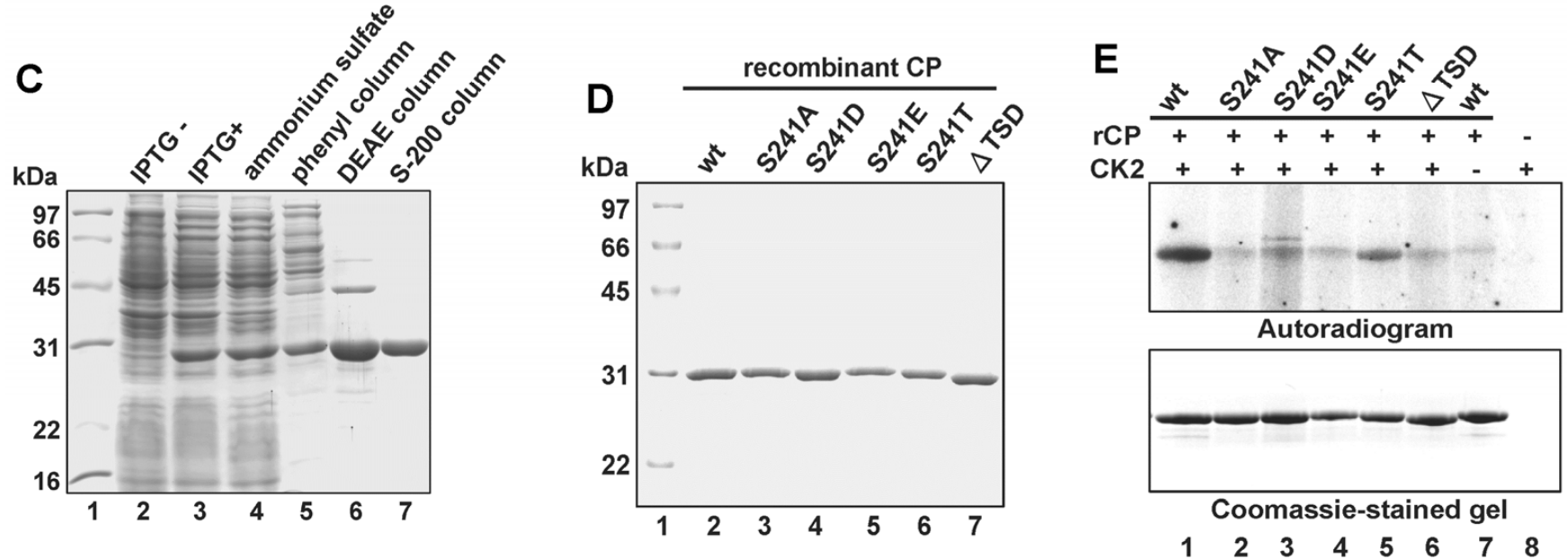

Fig. 2. S241 of Bamboo mosaic virus (BaMV) coat protein (CP) is phosphorylated by casein kinase $2 \alpha$ (CK2 $\alpha$ ). A, Examination of Escherichia coliexpressed CK2 $\alpha$ by polyacrylamide gel electrophoresis. GST-tagged recombinant CK2 protein was expressed in $E$. coli and purified. Protein samples were taken from each purification step and separated by electrophoresis in a 12\% polyacrylamide gel containing $1 \%$ sodium dodecyl sulfate (SDS polyacrylamide gel electrophoresis [PAGE]) and stained with Coomassie blue. B, Recombinant GST-CK2 is enzymatically active in vitro. The known substrate casein (1 $\mu \mathrm{g})$ was used to test the casein kinase activity of purified recombinant GST-CK2 in reactions containing $50 \mathrm{ng}$ of GST-CK2, and $0.5 \mu$ of $\gamma^{-32} \mathrm{P}-\mathrm{ATP}$ in reaction buffer, with or without the inhibitor heparin or the cold competitor GTP (indicated at the top of each lane). C, Examination of E. coli-expressed BaMV wildtype (WT) recombinant CP (rCP) by SDS-PAGE. The rCP protein was purified from E. coli using phenyl, DEAE, and S-200 chromatography consecutively. D, SDS-PAGE analysis of the final purification products of WT and mutant $\mathrm{rCP}$ from $E$. coli. By using the same steps as those applied for WT CP in C, the purified products of various mutant $\mathrm{rCP}$ were analyzed by SDS-PAGE and stained with Coomassie blue. E, In vitro phosphorylation of WT and S241T rCP by GST-CK2. Purified WT and mutant $\mathrm{rCP}(1 \mu \mathrm{g})$ were added to in vitro phosphorylation reaction mixtures, consisting of $50 \mathrm{ng}$ of GST-CK2 and $0.5 \mu \mathrm{l}$ of $\gamma^{-32} \mathrm{P}$-GTP, and incubated at $30^{\circ} \mathrm{C}$ for $30 \mathrm{~min}$. Reaction containing rCP or GST-CK2 alone were included as negative controls. 

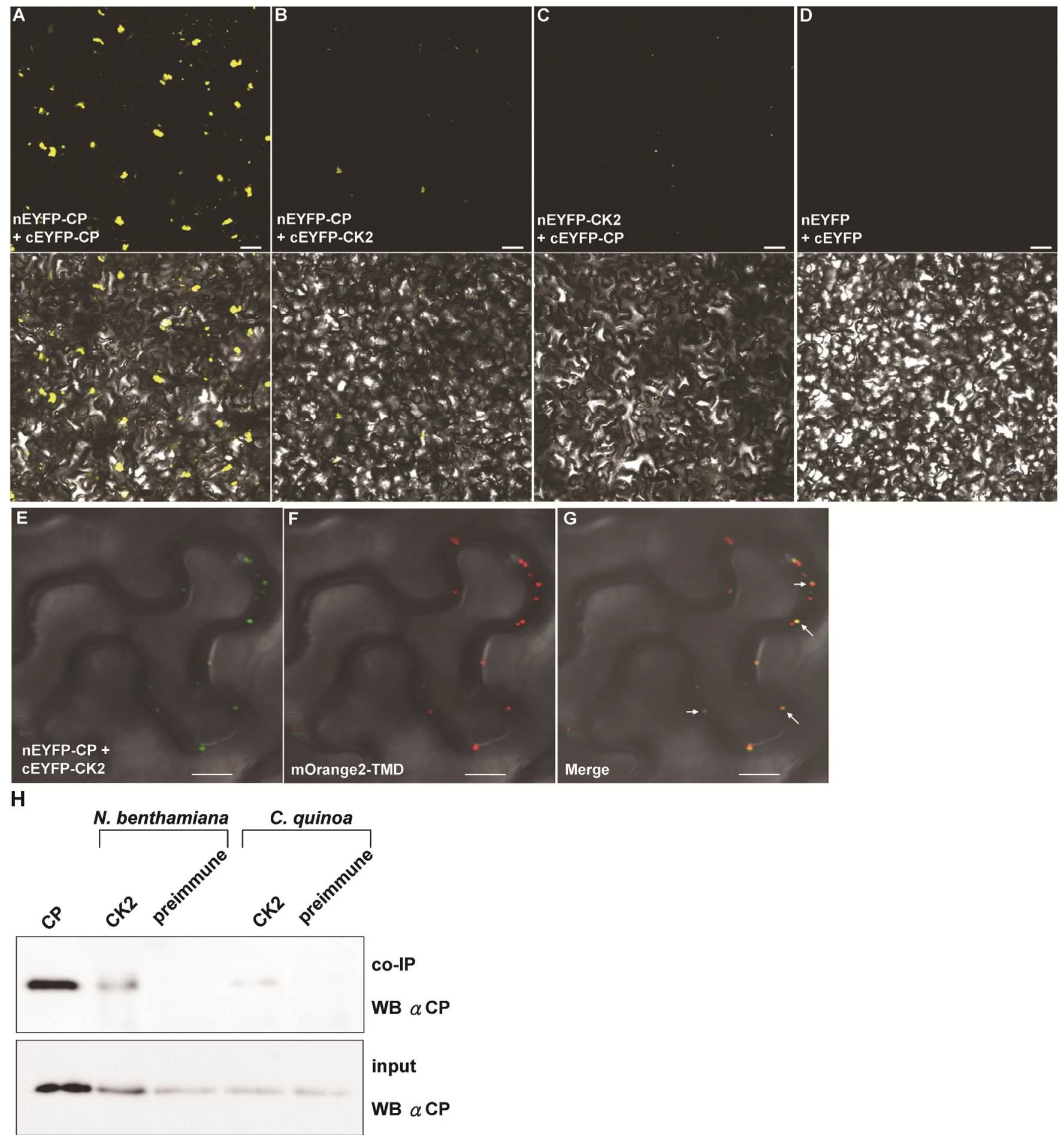

Fig. 3. Analysis of the interaction between coat protein (CP) and casein kinase $2 \alpha(\mathrm{CK} 2 \alpha)$ in Nicotiana benthamiana and Chenopodium quinoa using bimolecular fluorescence complementation (BiFC) or co-immunoprecipitation assays. A-D, Fluorescent micrographs of $N$. benthamiana leaf epidermal cells infiltrated with various combinations of enhanced yellow fluorescent protein (EYFP) fusion constructs, indicated in the lower left-hand corner of each panel. Constructs fused to the N- or C-terminal EYFP are denoted as nEYFP or cEYFP, respectively. The agroinfiltrated $N$. benthamiana leaves were examined by confocal microscopy for complementation of EYFP fluorescence at 2 days postinoculation (dpi). Bright-field images of the same areas are shown below each panel. Scale bars $=50 \mu \mathrm{m}$. E-G, Colocalization of NbCK2 $\alpha$ and BaMV CP at plasmodesmata (PD). BiFC constructs and the transmembrane domain (TMD) of PDLP1a fused to mOrange2 were agroinfiltrated into $N$. benthamiana leaves, which were subsequently examined by confocal microscopy at 3 dpi. E, EYFP channel; F, mOrange2 channel; and $\mathbf{G}$, merged images. Constructs infiltrated are shown in the lower left-hand corner of each panel. Scale bars $=10$ $\mu \mathrm{m}$. Arrows in G indicate overlap between EYFP and mOrange2 fluorescence signals. H, Co-immunoprecipitation (co-IP) assay to verify the interactions between BaMV CP and CK2 under BaMV-infection conditions. Protein extracts from BaMV-inoculated leaves of $N$ benthamiana and $C$. quinoa were immunoprecipitated by preimmune or CK2-specific antiserum. The precipitates were separated by SDS-PAGE, transferred to polyvinylidene difluoride membranes, and probed with CP-specific antiserum $(\alpha-\mathrm{CP})$ in Western blot analyses (WB). The presence of CP in the protein extracts was also verified by WB using $\alpha$-CP serum, as shown below (input). 
A
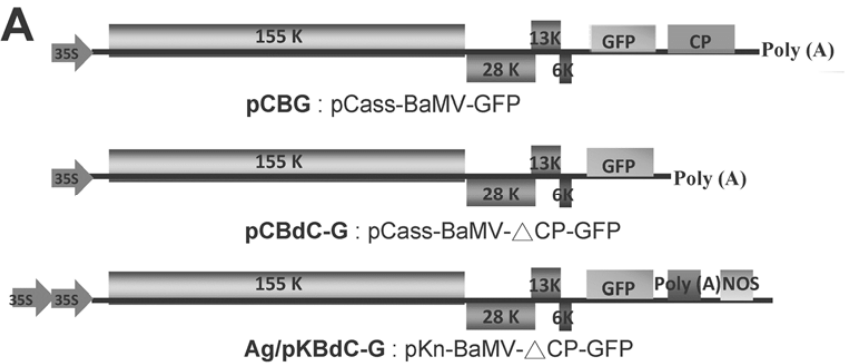

$\begin{array}{cc}\begin{array}{c}\text { Transient BaMV } \\ \text { CP expression } \\ \text { wt }\end{array} & \text { 35s } \\ \text { S241A } & \text { Ag/pKn-CP-wt } \\ \text { S241D } & \text { Ag/pKn-CP-S241A } \\ \text { S241E } & \mathrm{Ag} / \mathrm{pKn}-\mathrm{A} \text {-CP-S241D } \\ \text { S241T } & \mathrm{Ag} / \mathrm{pKn}-\mathrm{CP}-\mathrm{S} 241 \mathrm{~T} \\ \Delta \text { TSD } & \mathrm{Ag} / \mathrm{pKn}-\mathrm{CP}-\Delta \mathrm{TSD}\end{array}$
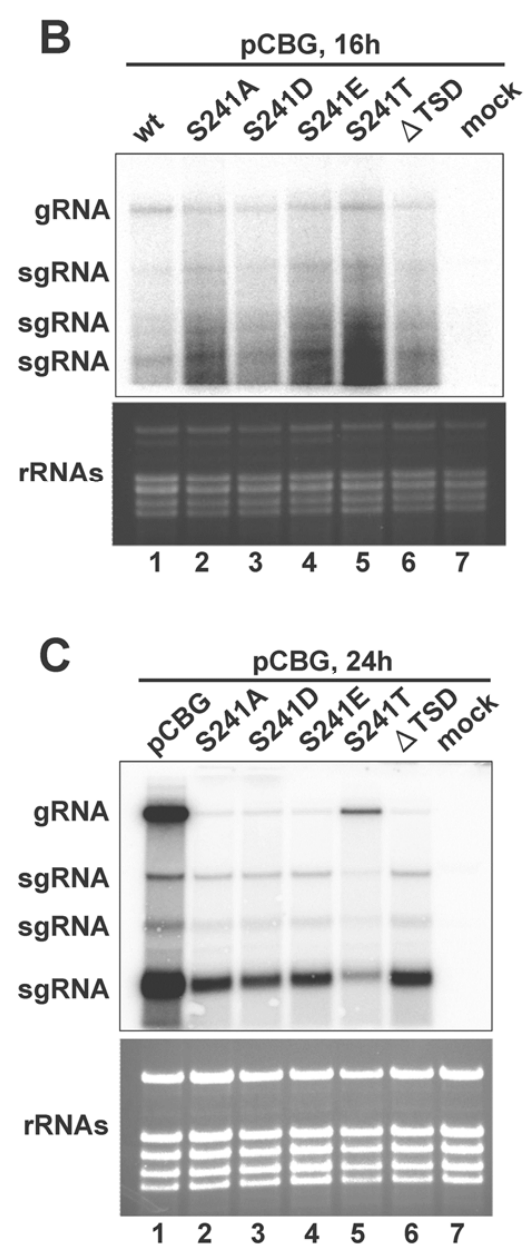
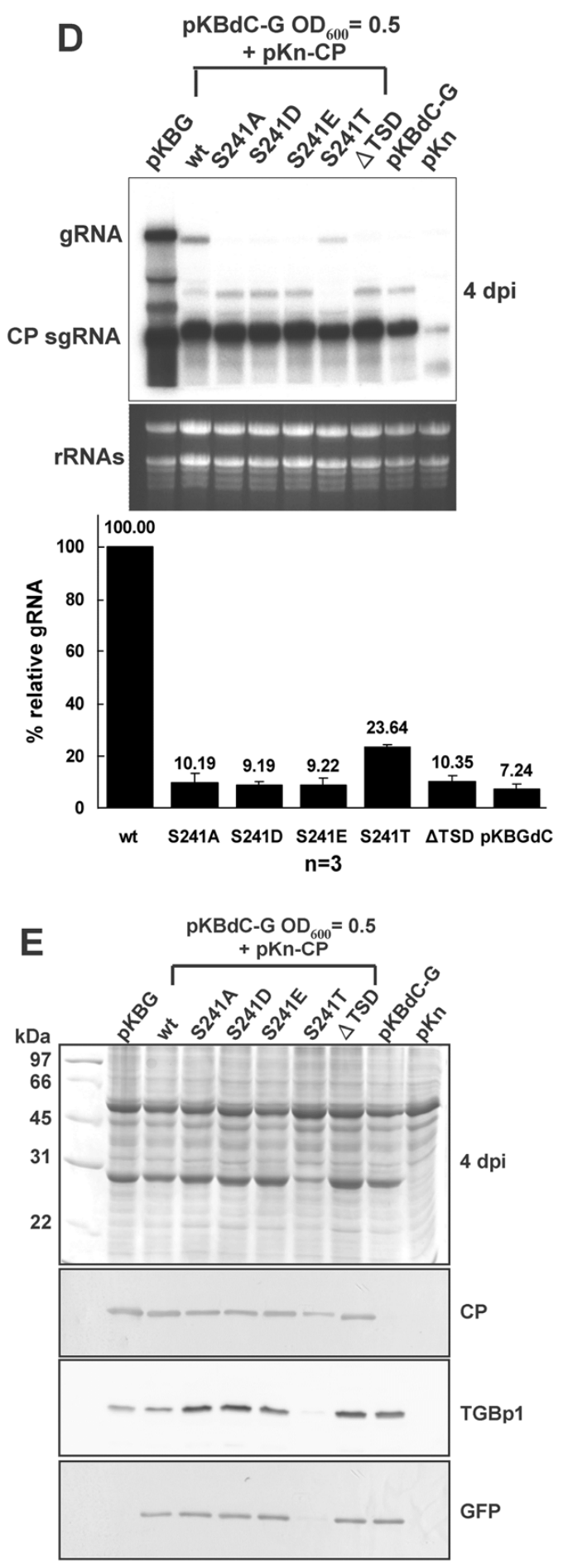

Fig. 4. Mutations at the $\mathrm{C}$ terminus of Bamboo mosaic virus (BaMV) coat protein (CP) have differential effects on the accumulation of viral genomic and subgenomic RNAs at early and late infection stages in vivo. A, Schematics of BaMV clone constructs. The pCass-based constructs were used for DNA inoculations and the pKn-based constructs for Agrobacterium-mediated infiltration. These constructs contain single or double copies of Cauliflower mosaic virus (CaMV) 35S promoter (represented by the arrows at the $5^{\prime}$-termini) to drive transcription in vivo. The $\mathrm{CP}$ coding sequence of pCB was replaced with that of green fluorescent protein (GFP) to create pCBdC-G. B and C, Northern blot analysis of total RNAs extracted from N. benthamiana protoplasts inoculated with pCBG and mutants thereof at $\mathbf{B}, 16$ and $\mathbf{C}, 24 \mathrm{~h}$ postinoculation (hpi). The membrane was hybridized with BaMV-specific RNA probes. Ethidium bromide-stained gels are shown below each panel as loading controls. D, Northern blot analysis of viral RNA in inoculated N. benthamiana leaves co-infiltrated with pKBdC-G and various constructs expressing wild-type (WT) and mutant CP. Equal amounts of Agrobacterium harboring pKBdC-G and various $\mathrm{CP}$-expressing constructs (optical density at $600 \mathrm{~nm}\left[\mathrm{OD}_{600}\right]$ of 0.75 ) were mixed and co-infiltrated into $N$. benthamiana leaves. Agrobacterium harboring pKBG or pKn (at an $\mathrm{OD}_{600}$ of 0.5 ) served as a positive or negative control, respectively. Total RNAs were extracted from inoculated leaves of $N$. benthamiana at 4 days postinoculation (dpi) and subjected to Northern blot hybridization using a BaMV-specific probe. Levels of genomic RNAs were quantified relative to that of the WT, as shown in the chart below. All data are averages ( \pm standard deviation) of three independent experiments. E, Western blot analysis of the protein products of the major subgenomic RNAs (TGBp1 and GFP) of pKBG and transient expression levels of various CP in co-infiltrated N. benthamiana leaves at $4 \mathrm{dpi}$. The presence of protein products was detected by specific antibodies against CP, TGBp1, and GFP, as indicated on the right of each panel. The Coomassie blue-stained gel (top panel) served as the loading control. 
(TMD) of PDLP1a, a PD-targeting protein (Thomas et al. 2008), to the mOrange 2 fluorescent protein. This revealed that reconstructed YFP fluorescence colocalized with TMD-tagged mOrange 2 at PD (Fig. 3E through G). These results indicate that BaMV CP and NbCK2 $\alpha$ may interact at PD in infected $N$. benthamiana. To further test whether BaMV CP interacts with CK2 $\alpha$ in plants under infection conditions, co-immunoprecipitation experiments were performed. The interaction between BaMV CP and CK2 $\alpha$ were analyzed in both a systemic host (N. benthamiana) and a local lesion host (Chenopodium quinoa). At $7 \mathrm{dpi}$, protein extracts from leaves inoculated with BaMV virions were subjected to immunoprecipitation with pre-immune or anti-CK $2 \alpha$ antibodies, followed by Western blot analysis using antibodies specific to BaMV CP. The result revealed that $\mathrm{BaMV} \mathrm{CP}$ was present in the precipitates from both plants generated by anti-CK2 $\alpha$ but not the pre-immune antibodies, indicating that BaMV CP could directly interact with CK2 $\alpha$ in BaMV-infected $N$. benthamiana and $C$. quinoa (Fig. $3 \mathrm{E})$. Although the result did not exclude the involvement of other kinases, such as glycogen synthase kinase 3 (Zhang et al. 2010) and calcium/calmodulin-dependent kinases II (Yang et al. 2010), it demonstrated that BaMV CP could interact with and likely be phosphorylated by CK2 $\alpha$ in BaMV-infected plants.

\section{Point mutations in the CK2 $\alpha$ phosphorylation site of CP affect vRNA accumulation.}

To evaluate the effects of $\mathrm{CP}$ phosphorylation on BaMV infection cycles, we constructed several mutants based on the in-

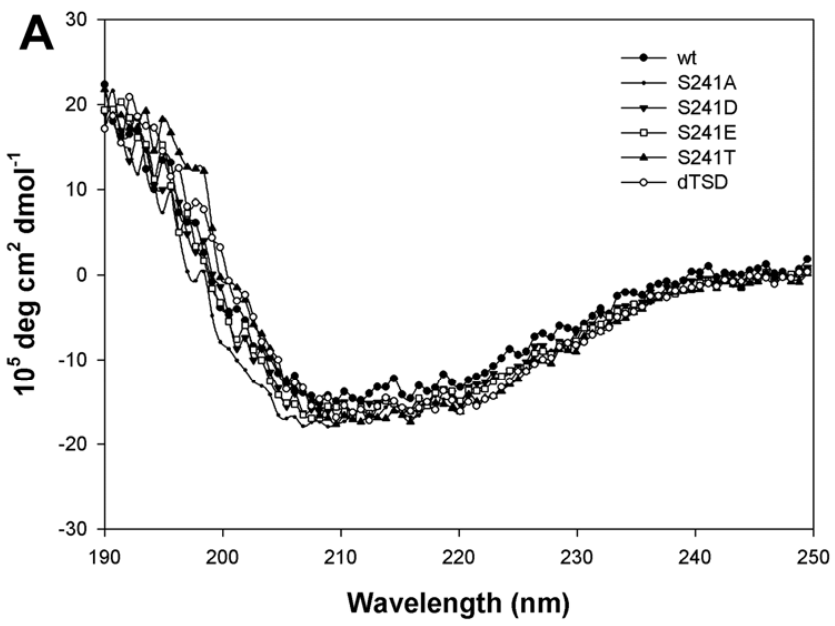

B

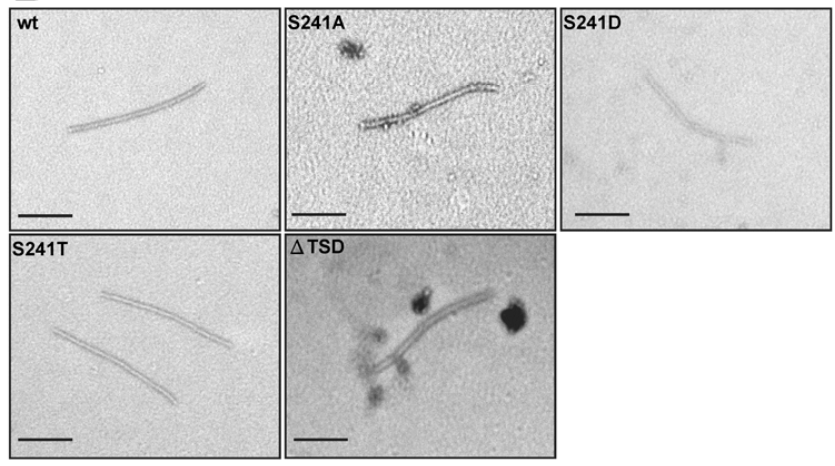

Fig. 5. Mutations of the $\mathrm{C}$ terminus of Bamboo mosaic virus (BaMV) coat protein $(\mathrm{CP})$ do not significantly alter the structure of virions. A, Circular dichroism (CD) spectra of purified CP (the wild type [WT] or the indicated mutant; $19.5 \mu \mathrm{g} / \mathrm{ml}$ each, in $2 \mathrm{mM}$ phosphate buffer within $5-\mathrm{mm}$ cuvettes), obtained using a Jasco J-815 CD spectrometer. B, Transmission electron micrographs of purified virions of WT and the indicated CP mutants. All images are at the same magnification. Scale bar $=200 \mathrm{~nm}$. fectious clone pCBG (Fig. 4A) to express the aforementioned mutant $\mathrm{CP}$. The effects of the mutants on vRNA accumulation were assayed in $N$. benthamiana protoplasts. Total RNAs were extracted from protoplasts inoculated with WT pCBG (WT) or mutants at 16 and $24 \mathrm{~h}$ postinoculation (hpi), and analyzed by Northern blot hybridization. No significant differences in the accumulation of viral genomic and CP subgenomic RNAs were observed in protoplasts inoculated with WT or mutants at 16 hpi (Fig. 4B), suggesting that the replication of viral genomic RNAs and the transcription of subgenomic RNAs were not significantly affected by the mutations. In contrast, levels of genomic and CP subgenomic RNAs were reduced in all mutants at 24 hpi compared with those of the WT (Fig. 4C). Furthermore, all CP mutations, except S241T, exhibited a significant decrease in accumulation of genomic RNAs compared with subgenomic RNAs at 24 hpi (Fig. 4C, lanes 2, 3, 4, and 6) whereas, in S241T, levels of genomic RNA exceeded those of subgenomic RNAs at 24 hpi (Fig. 4C, lane 5). In addition, levels of genomic and subgenomic RNAs in S241T at 24 hpi were higher and lower, respectively, than those in the other mutants. Similar results were observed for all three replicates of the inoculation assays. These results suggest that the CP mutations had differential effects on the accumulation of genomic and subgenomic RNAs at 24 hpi but did not affect replication and transcription at the early stage of the infection cycle (16 hpi).

To distinguish between the effects of altered RNA sequences or mutated proteins on the accumulation of vRNAs, the following trans-complementation experiments were performed. The coding sequences of WT and mutant $\mathrm{CP}$ were subcloned into the $\mathrm{pKn}$ vector to generate $\mathrm{pKn}-\mathrm{CP}, \mathrm{pKn}-\mathrm{S} 241 \mathrm{~A}, \mathrm{pKn}-\mathrm{S} 241 \mathrm{D}, \mathrm{pKn}-$ S241E, pKn-S241T, and pKn- $\Delta$ TSD. The CP ORF of pKB, a $\mathrm{BaMV}$ infectious clone, was replaced with that of green fluorescent protein (GFP) to generate pKBdC-G (Fig. 4A) as a reporter construct. The WT and mutant BaMV CP were provided in trans by co-infiltration of Agrobacterium tumefaciens mixtures harboring pKBdC-G and the pKn-based WT or mutant CPexpression constructs into $N$. benthamiana. Plants infiltrated with A. tumefaciens harboring $\mathrm{pKBG}$ or $\mathrm{pKn}$ served as positive and negative controls, respectively. Total RNAs were isolated at 4 dpi and analyzed by Northern blot hybridization with BaMV-specific probes. The results revealed that the levels of reporter pKBdC-G genomic RNA in plants cosupplied with S241A, S241D, S241E, S241T, and $\Delta$ TSD decreased to 10.2, $9.2,9.2,23.6$, and $10.4 \%$, respectively, of that in plants supplied with the WT (Fig. 4D). Similar RNA accumulation patterns were observed in trans-complementation and protoplast assays (Fig. 4C and D). In addition, Western blot analysis revealed that CP, GFP, and TGBp1 accumulated to similar levels in plants inoculated with WT and all mutants, with the exception of S241T, in which mutant CP was slightly reduced and GFP and TGBp1 were reduced to almost nondetectable levels

Table 1. Comparison of the levels of virions from plants inoculated with coat protein $(\mathrm{CP})$-deficient $\mathrm{pKBdC}-\mathrm{G}$ and $\mathrm{pKn}-\mathrm{CP}$ constructs expressing wild-type (WT) or mutant $\mathrm{CP}$

\begin{tabular}{lccc}
\hline Construct & Amount $(\mathbf{n g} / \mathbf{g})$ & ${\text { Percent }(\boldsymbol{\%})^{\mathbf{a}}}^{\mathbf{a}}$ & Relative gRNA (\%) $^{\mathbf{b}}$ \\
\hline WT & 6,000 & 100 & 100 \\
S241A & 125 & 2.1 & 10.2 \\
S241D & 167 & 2.8 & 9.2 \\
S241E & 167 & 2.8 & 9.2 \\
S241T & 2,055 & 34.3 & 23.6 \\
$\Delta$ TSD & 147 & 2.5 & 10.4 \\
\hline
\end{tabular}

${ }^{\text {a }}$ Percentages of purified virions were normalized to the amount of WT virion.

${ }^{\mathrm{b}}$ Percentages of mutant genomic RNA are expressed relative to the level of WT genomic RNA (gRNA). 

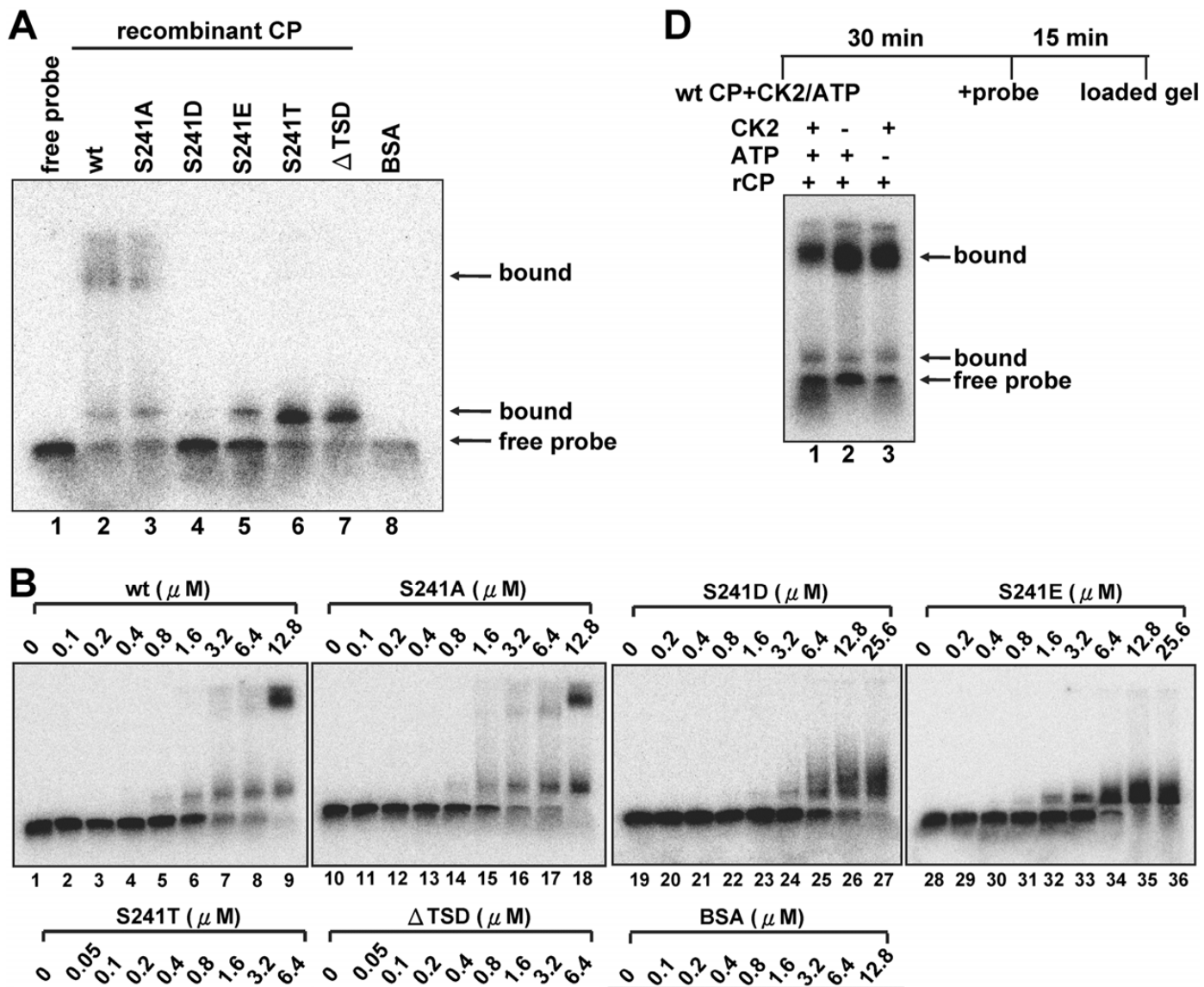

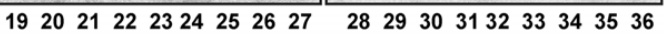
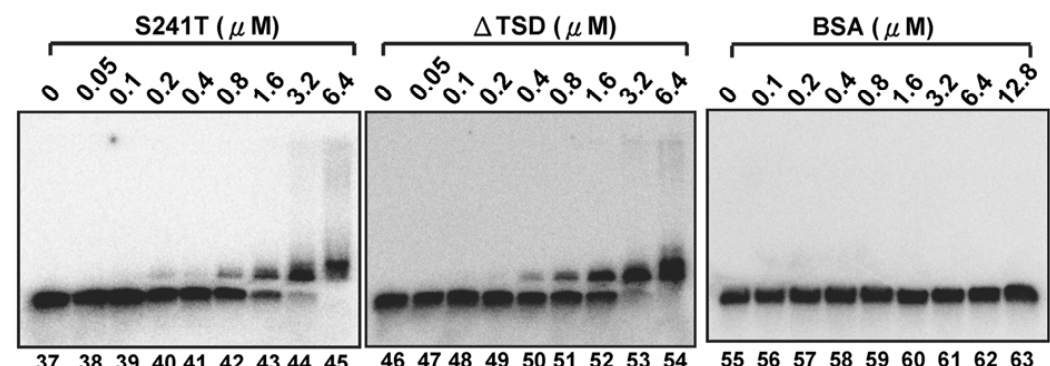

C

555657585960616263

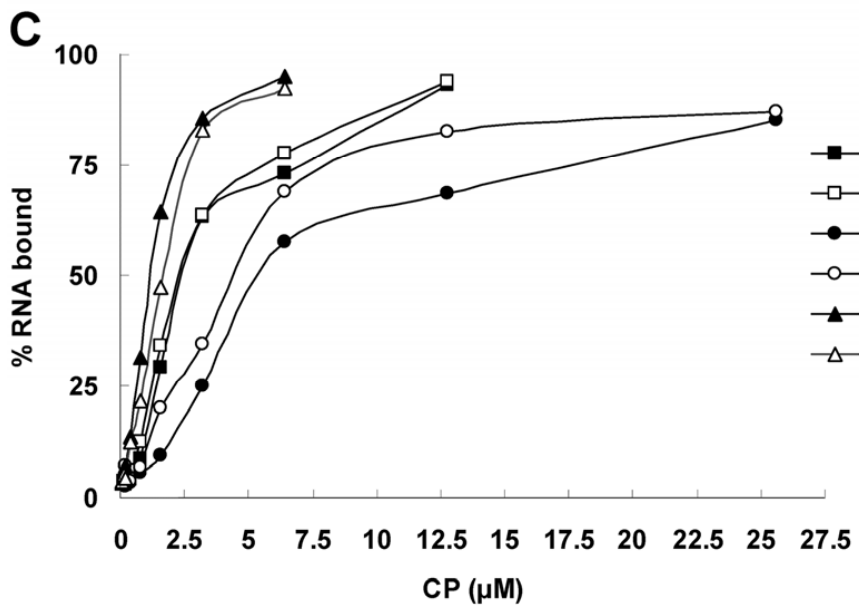

Fig. 6. Phosphorylation at the $\mathrm{C}$ terminus of Bamboo mosaic virus (BaMV) coat protein (CP) reduces its affinity to viral RNA. A, Electrophoretic mobility shift assay (EMSA) was used to examine the affinity between various BaMV CP and viral RNA. Radiolabeled probes (1 fmol) corresponding to the 5' untranslated region (UTR) of BaMV genomic RNA were incubated alone (lane 1), with $500 \mathrm{ng}(2 \mu \mathrm{M})$ of various CP (lanes $2-7$, as indicated at the top of each lane), or with $1 \mu \mathrm{g}(2 \mu \mathrm{M})$ of bovine serum albumin (BSA, lane 8), in a 10- $\mu$ l reaction buffer for $15 \mathrm{~min}$. BSA was used as a negative control. Samples were analyzed by electrophoresis through a $1 \%$ agarose gel in $0.5 \times$ Tris-borate-EDTA. B, Determination of the affinity between BaMV genomic RNA $5^{\prime}$ UTR and the indicated CP by EMSA. Radiolabeled RNA probes $(1 \mathrm{fmol})$ were added to twofold serial dilutions of purified CP and BSA (as indicated on the top of each lane), and incubated as described above. BSA was used as a negative control. C, Quantification of the interactions between BaMV RNA 5' UTR and the indicated CP. Percentages of RNA bound to various CP are plotted against the CP concentration. The fraction of bound RNA was determined using the equation $I_{s} /\left(I_{s}+I_{f}\right)$, where $I_{s}$ is the sum of intensities of all shifted bands and $I_{f}$ is the intensity of the unbound (free) probes. D, Effect of phosphorylation on the binding of BaMV CP to RNA 5' UTR. EMSA was performed as shown in the schematic at the top of the panel. Purified CP (1 $\mu \mathrm{g})$ were preincubated with $50 \mathrm{ng}$ of casein kinase 2 (CK2) (lanes 1 and 3) or with (lanes 1 and 2) or without (lane 3 ) $1 \mathrm{mM}$ ATP. After incubation for 30 min at $30^{\circ} \mathrm{C}$, RNA binding was initiated by the addition of a radiolabeled RNA probe $(1 \mathrm{fmol})$ and the reactions were incubated for $15 \mathrm{~min}$. 
(Fig. 4E). The reduction in GFP and TGBp1 levels was likely due to the decreased amounts of subgenomic RNAs, suggesting that the CP S241T mutant has a strong preference for viral genomic RNA over subgenomic RNA. These results indicate

Table 2. Dissociation constants $\left(K_{d}\right)$ and Hill coefficients for the interactions between Bamboo mosaic virus genomic RNA 5' untranslated region and the indicated coat proteins

\begin{tabular}{lcc}
\hline Coat protein & $\boldsymbol{K}_{\boldsymbol{d}}(\boldsymbol{\mu M})$ & Hill coefficient \\
\hline Wild type & $2.83 \pm 0.03$ & $1.67 \pm 0.16$ \\
S241A & $2.46 \pm 0.10$ & $1.58 \pm 0.11$ \\
S241D & $6.84 \pm 0.77$ & $1.41 \pm 0.14$ \\
S241E & $4.77 \pm 0.43$ & $1.39 \pm 0.26$ \\
S241T & $1.13 \pm 0.13$ & $1.69 \pm 0.25$ \\
$\Delta$ TSD & $1.43 \pm 0.15$ & $1.63 \pm 0.07$
\end{tabular}

that mutations at S241 of CP have differential effects on the accumulation of viral genomic and subgenomic RNAs.

\section{CP mutants share similar structures with the WT.}

We subsequently used circular dichroism (CD) spectroscopy to investigate whether the aforementioned mutations caused significant changes to the structure of BaMV CP. No major differences were observed between the CD spectra (Fig. 5A), indicating that the mutations do not significantly affect its structure. To test whether S241 of CP is required for normal virion morphology, virions were purified from $N$. benthamiana leaves co-infiltrated with $\mathrm{pKBdC}-\mathrm{G}$ and $\mathrm{pKn}-\mathrm{CP}$ constructs expressing WT or mutant CP (similar to those used in the experiments depicted in Figure 4D) at 4 dpi. The yields of purified BaMV virions from the infiltrated leaves are listed in
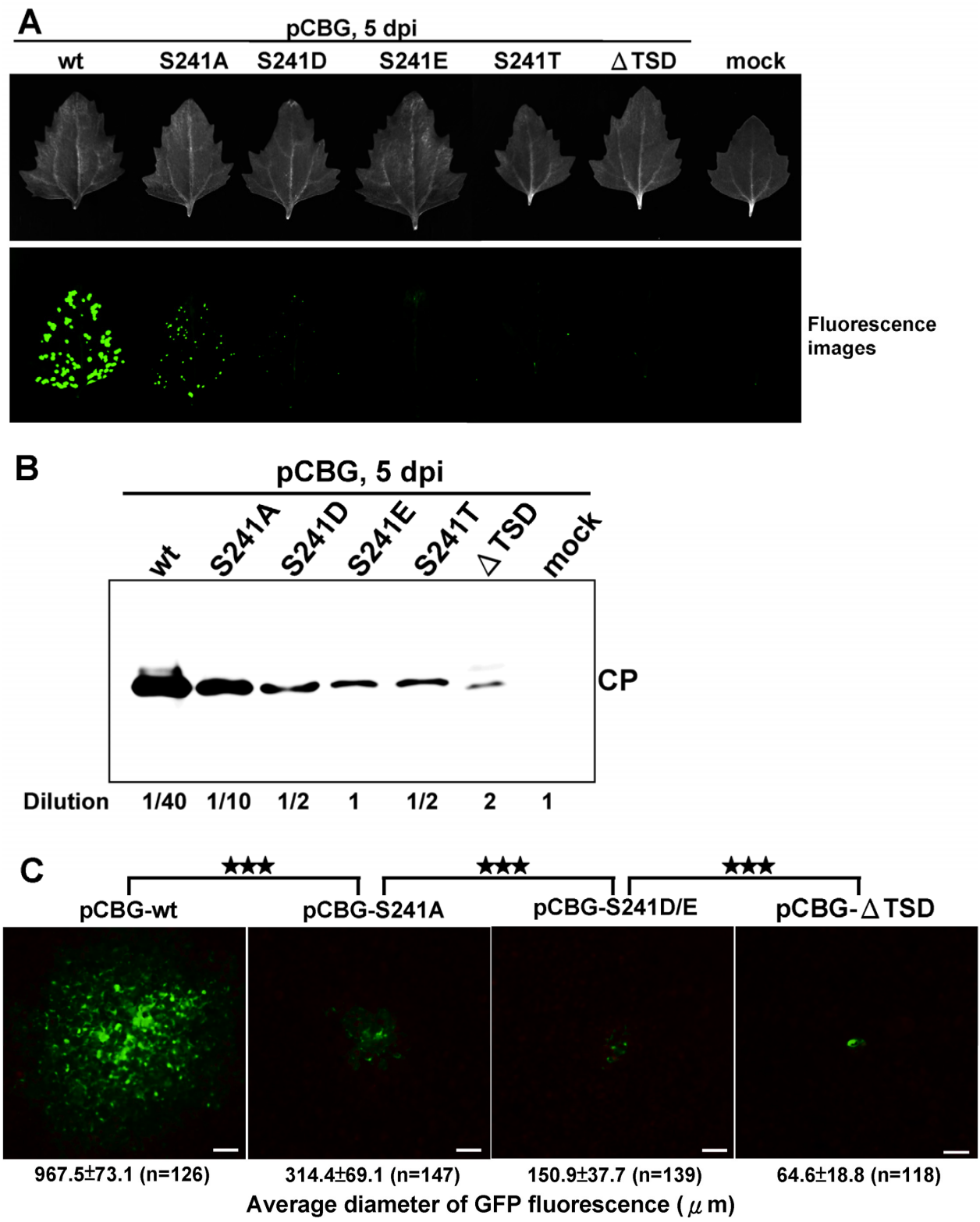

Fig. 7. Effects of mutations at the $\mathrm{C}$ terminus of Bamboo mosaic virus (BaMV) coat protein (CP) on cell-to-cell movement. Chenopodium quinoa leaves were inoculated with wild-type (WT) pCBG or the indicated pCBG-derived mutants, and the spread of green fluorescent protein (GFP) fluorescence was examined at 5 days postinoculation (dpi). A, Spread of GFP fluorescence in inoculated leaves, observed using a Fujifilm LAS-4000 imaging system. C. quinoa leaves inoculated with the indicated infectious clones were examined under normal light (upper panel) or excitation light for GFP fluorescence (lower panel). B, Western blot analysis of BaMV CP in inoculated leaves. Total proteins of the inoculated C. quinoa leaves were detected using BaMV CP-specific antisera. To accommodate the large differences in CP levels between constructs, different dilutions (shown below each lane) of each sample were loaded. C, Microscopic observation of the infection foci induced by WT pCBG and the indicated mutants. Diameters of fluorescent foci in $C$. quinoa leaves were visualized and measured under fluorescence microscopy. Values with statistically significant differences are indicated; $* * *=P$ value $<0.001$. Scale bar $=100 \mu m$. 
Table 1. A high degree of correlation was observed between the quantities of virions and the accumulation of genomic RNAs (Table 1; Fig. 4D). To further verify the effects of CP mutations on virion morphology, purified virions were negatively stained and examined by transmission electron microscopy (TEM). Regardless of origin, all trans-assembled virus particles had the typical size and morphology of BaMV (Fig. 5B). These results confirm that mutant $\mathrm{CP}$ retain the ability to assembly into viral particles.

\section{Mutations mimicking a phosphorylated-serine at the $\mathrm{C}$ terminus of $\mathrm{CP}$ reduced affinity to vRNA.}

We previously identified that two key amino acids (R99 and R227) are required for the RNA binding ability of BaMV CP, and demonstrated that mutations at these sites affect virion formation and the accumulation of genomic but not subgenomic RNA (Hung et al. 2014). Here, we report that mutations at the $C$ terminus of $\mathrm{CP}$ also reduce the accumulation of viral genomic RNAs and virions (Fig. 4D; Table 1). It has been shown that the $5^{\prime}$ untranslated region (UTR) of PVX genomic RNA is involved in regulating virus replication, cell-to-cell movement, and virion assembly (Verchot-Lubicz et al. 2007). Therefore, we examined whether phosphorylation of the $\mathrm{C}$ terminus of $\mathrm{CP}$ would affect its binding to BaMV $5^{\prime}$ UTR by using electrophoretic mobility shift assays (EMSA) with a ${ }^{32} \mathrm{P}$-labeled BaMV 5' UTR RNA probe and nonphosphorylated BaMV CP (WT and various mutants, expressed and purified from E. coli) (Fig. 2D). The result revealed that S241D and S241E reduce vRNA binding, whereas S241T and $\triangle \mathrm{TSD}$ increase affinity to vRNA (Fig. 6A). It should be noted that two major shifted bands were observed in the EMSA experiments, suggesting that either the $5^{\prime}$ UTR has at least two CP binding sites or RNA-protein complexes of different sizes or conformations were formed. We calculated the dissociation constants $\left(K_{d}\right)$ for the binding between BaMV $5^{\prime}$ UTR and various $\mathrm{CP}$ using the data from EMSA experiments. The fractions of shifted RNA probes (Fig. 6B and C) with increasing amounts of various CP were used to calculate the respective $K_{d}$ values, as previously described (Ryder et al. 2008). WT and S241A CP showed a similar affinity to BaMV RNA 5' UTR (Table 2). In contrast, the $K_{d}$ values of S241D and S241E CP were approximately twofold higher than that of WT CP. On the other hand, the $K_{d}$ values for the interactions between S241T and $\triangle \mathrm{TSD}$ and BaMV RNA $5^{\prime}$ UTR were approximately twofold lower than that of the WT, suggesting that S241T and $\triangle \mathrm{TSD}$ CP may form tighter complexes with BaMV genomic RNA in the nonphosphorylated state (because the proteins were expressed from $E$. coli and, thus, could not be phosphorylated). The Hill coefficients for the interactions between the CP and BaMV RNA 5' UTR ranged from 1.39 to 1.69 , indicating that the CP binds to BaMV RNA in a positively cooperative manner. To determine whether CK2 $\alpha$-phosphorylated CP interacts with BaMV RNA in a similar manner to the S241D and S241E mutations, WT CP was incubated with CK2 $\alpha$ and cold-ATP for 30 min and then subjected to EMSA (Fig. 6D). CK2 $\alpha$-phosphorylation of WT CP was found to decrease its RNA binding ability (lane 1), while the addition of CK2 $\alpha$ (lane 3) or ATP (lane 2) alone did not affect the interaction between $\mathrm{CP}$ and BaMV RNA. Therefore, these results demonstrate that CK2 $\alpha$-phosphorylation of BaMV CP at S241 inhibits its binding to vRNA, which is likely due to negative charge repulsion; conversely, the S241T and $\triangle$ TSD mutations may assemble into tighter complexes with BaMV RNA.

\section{Cell-to-cell movement is impaired by mutations at S241 of CP.}

To further explore the effects of BaMV CP phosphorylation at $\mathrm{S} 241$ on the virus infection cycle, we inoculated $C$. quinoa leaves with the WT infectious clone (pCBG) or its derived mutants (S241A, D, E, T, or $\Delta \mathrm{TSD})$. C. quinoa is a local lesion host for BaMV, which inflicts round-shaped lesions for easy
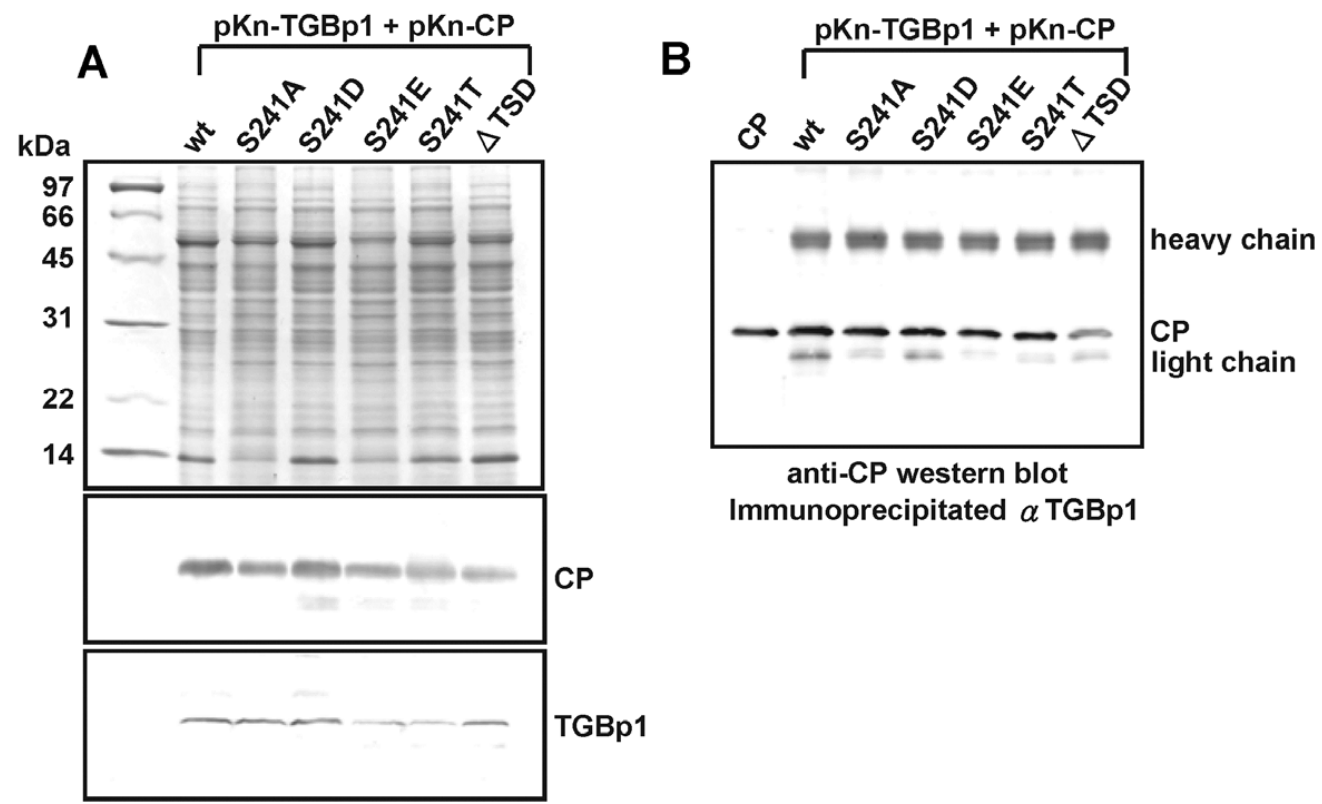

anti-CP western blot Immunoprecipitated $\alpha$ TGBp1

Fig. 8. Analysis of interactions between Bamboo mosaic virus (BaMV) TGBp1 and various coat proteins (CP) by co-immunoprecipitation assays. Nicotiana benthamiana leaves were co-infiltrated with Agrobacterium (optical density at $600 \mathrm{~nm}=0.5$ ) harboring pKn-TGBp1 and pKn-based plasmids for the expression of the indicated CP.. Proteins were extracted from infiltrated leaves at 2 days postinoculation (dpi) and subjected to analysis by co-immunoprecipitation. A, Confirmation of the expression of TGBp1 and various CP in plants by Western blot analyses. Protein samples ( $30 \mu \mathrm{g}$ ) were separated by sodium dodecyl sulfate polyacrylamide gel electrophoresis (SDS-PAGE), and either stained with Coomassie blue (upper panel) or transferred to polyvinylidene difluoride (PVDF) membranes for probing with antisera specific to CP (middle panel) or TGBp1 (lower panel). B, Co-immunoprecipitation assay. Protein samples (500 $\mu \mathrm{g}$ ) were incubated with TGBp1-specific antibody and protein A beads. Precipitated samples were separated by SDS-PAGE, transferred to PVDF membranes, and probed with CP-specific antisera. Identities of the samples are indicated at the top of each lane. 
measurement and comparison of cell-to-cell movement abilities of WT BaMV and various mutants. The CK2 $\alpha$ genes of $C$. quinoa have been partially sequenced and shown to share more than $80 \%$ similarity with that of NbCK $2 \alpha$ (C.-J. Hung and Y.-H. Hsu, unpublished data), and the interaction between the CK2 $\alpha$ and BaMV CP has been demonstrated by coimmunoprecipitation assays, as described above (Fig. 3H). In inoculated leaves, GFP can only be expressed from subgenomic RNA generated using negative-strand BaMV genomic RNA as template and, therefore, the presence and spread of green fluorescence serve as indicators of successful BaMV replication and cell-to-cell movement, respectively. Green fluorescence was observed to spread in inoculated leaves at $5 \mathrm{dpi}$ (Fig. 7A). Fluorescence was strong in leaves inoculated with WT or S241A but weak in those inoculated with other mutants. To examine the accumulation of BaMV $\mathrm{CP}$, total proteins were extracted from the inoculated leaves at $5 \mathrm{dpi}$ and analyzed by Western blot (Fig. 7B). Clear differences in CP accumulation were observed among leaves inoculated with the WT or mutants: levels of WT CP were approximately 5 times greater than that of S241A; approximately 50 times greater than those of S241D, S241E and S241T; and approximately 160 times greater than that of $\triangle \mathrm{TSD}$. To further investigate how the mu- tations affect viral cell-to-cell movement, we monitored the diameter of green fluorescence foci in $C$. quinoa leaves at $5 \mathrm{dpi}$ using an Olympus IX71 inverted microscope. Green fluorescent foci were not observed in leaves inoculated with S241T, which was likely a consequence of low subgenomic RNA levels for GFP (Fig. 4C and E). The average diameters of fluorescent foci induced by the BaMV mutants were smaller than those induced by the WT at 5 dpi (Fig. 7C), being approximately $32.5,15.5$, and $6.6 \%$ of that of the WT $(967.5 \pm 73.1$ $\mu \mathrm{m})$ for S241A $(314.4 \pm 69.1 \mu \mathrm{m}), \mathrm{S} 241 \mathrm{D} / \mathrm{E}(150.9 \pm 37.7$ $\mu \mathrm{m})$, and $\Delta \mathrm{TSD}(64.6 \pm 18.8 \mu \mathrm{m})$, respectively. Although the genomic RNA levels of the mutants were significantly lower than that of WT BaMV, all mutants, except S241T, shared similar levels (Fig. 4B through D); therefore, the significant differences in the sizes of infection foci between plants inoculated with different mutants suggest that the phosphorylation status at S241 of BaMV CP may affect cell-to-cell movement.

\section{CP mutants interact with TGBp1.}

It has been shown that BaMV CP can interact with TGBp1 (Wu et al. 2011). Thus, we tested whether the observed differences in cell-to-cell movement are related to altered interactions between the mutant CP and TGBp1. Agrobacterium-

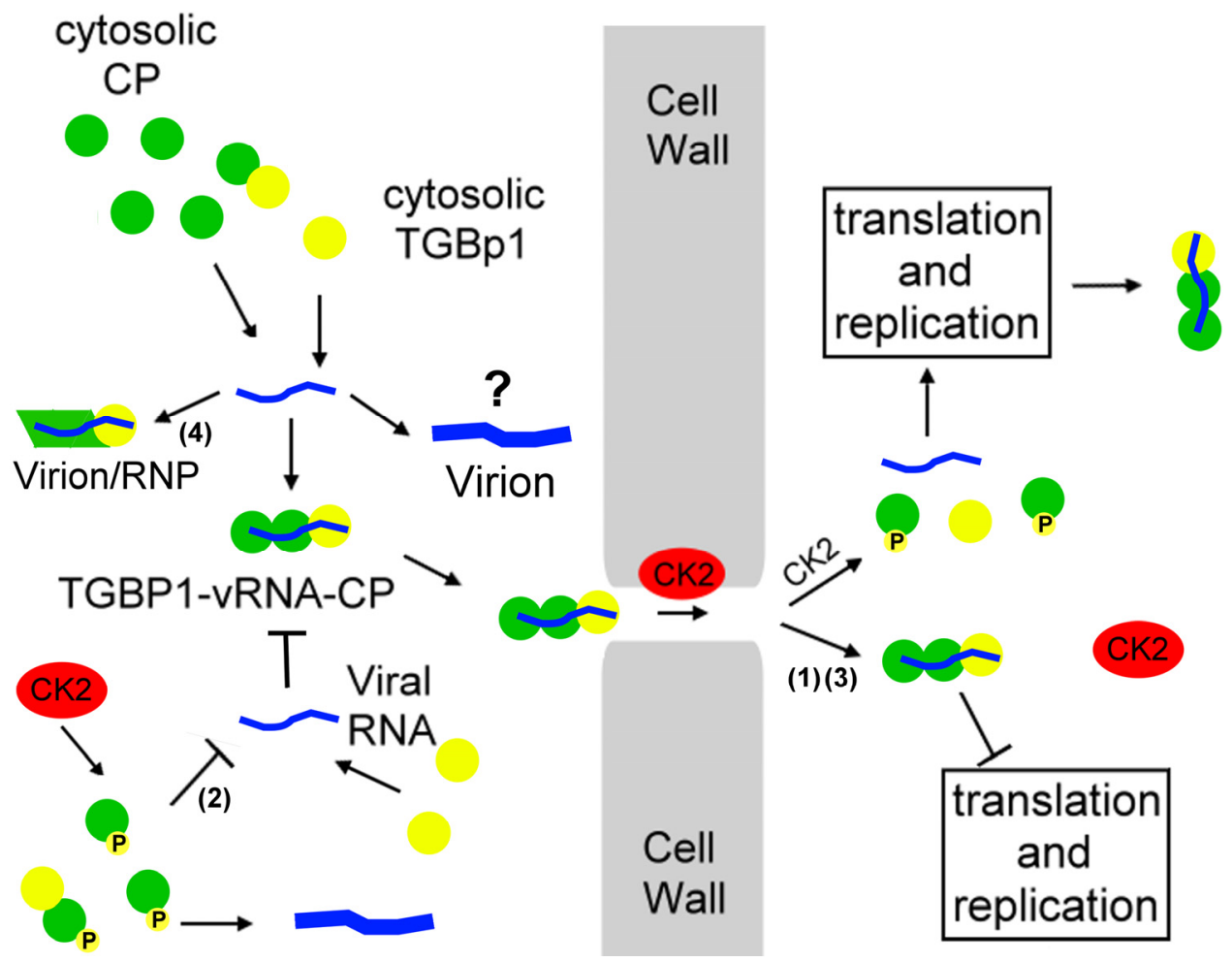

Fig. 9. Simplified model of the process by which phosphorylation of coat protein (CP) by Nicotiana benthamiana $\mathrm{CK} 2 \alpha(\mathrm{NbCK} 2 \alpha)$ regulates cell-to-cell movement of Bamboo mosaic virus (BaMV). The involvement of TGBp2 and TGBp3 has been omitted from this model for clarity. Following gene expression in the primary infected cell, viral RNA, cytosolic triple-gene-block protein 1 (TGBp1), and cytosolic coat protein (CP) can assemble into either a ribonucleoprotein (RNP) movement complex or a virion for cell-to-cell movement. When passing through the plasmodesmata (PD), wild-type (WT) CP can be phosphorylated by CK2 $\alpha$ at PD; this facilitates the uncoating process by reducing the affinity between CP and viral RNAs. Thus, the viral RNAs of WT BaMV can serve as templates for translation and replication in secondary infected cells. If phosphorylation at S241 is inhibited without significantly affecting the affinity between CP and viral RNAs (for example, the S241A mutation), assembly of RNP complexes and virions would not be affected; however, the efficiency of disassembly would be reduced in the secondary infected cells, decreasing the sizes of infection foci and accumulation of virions. Premature phosphorylation of CP in the cytosol (as mimicked by S241D/E CP) may block the formation of RNP complexes for efficient cell-to-cell movement, resulting in reduced movement capability. Removal of the phosphorylation signal around S241 (as in mutant $\Delta \mathrm{TSD}$ ) increases affinity to viral RNAs; this does not affect RNP or virion assembly or their movement into neighboring cells but may disrupt the disassembly process by increasing the affinity between CP and viral RNA, thereby preventing further translation and replication and decreasing the size of infection foci. Mutations of S241 (such as S241T) that increase the affinity between CP and viral RNAs and enhance binding toward the 5' UTR of viral genomic RNA may enable rapid assembly of viral genomic RNA into a different form of RNP or tightly bound virion in the primary infected cell; this may prevent the genomic RNA from serving as a template for further translation, replication, and generation of subgenomic RNAs and, consequently, impair infectivity in plants. Green circles $=\mathrm{CP}$, yellow circles $=\mathrm{TGBp} 1$, red ovals = CK2, blue thin filaments = BaMV RNA, blue thick filaments = BaMV virions, and green circles with small yellow circles labeled "p" = phosphorylated CP. Features regarding assembly of virions in this model have not been verified experimentally and, thus, are labeled with question marks. 
mediated co-infiltration was used to transiently coexpress TGBp1 and mutant CP in $N$. benthamiana leaves, and the resulting interactions were analyzed by co-immunoprecipitation. The expression levels of each CP and TGBp1 were confirmed by sodium dodecyl sulfate polyacrylamide gel electrophoresis (SDS-PAGE) analysis followed by Coomassie blue staining and Western blot (Fig. 8A). The WT and all mutant CP were detected in complexes precipitated with TGBp1-specific antibodies (Fig. 8B), indicating that the mutations did not affect the interactions between CP and TGBp1. Thus, the differences in cell-to-cell movement may be attributed to changes in the interactions between $\mathrm{CP}$ and vRNAs, and not those between CP and TGBp1.

\section{DISCUSSION}

Protein phosphorylation is a common mechanism of functional modulation, which can alter biological activity, subcellular localization, and interactions with other bio-molecules (Cohen 2000). In potexviruses, CK2 has been demonstrated to phosphorylate TGBp1 (Modena et al. 2008), and this was proposed to be involved in the regulation of PVX movement (Verchot-Lubicz et al. 2010). In addition, phosphorylation of PVX CP has been demonstrated to be involved in the translational activation of encapsidated PVX genomic RNA in primary inoculated cells (Atabekov et al. 2001). However, the effects of CP phosphorylation on the movement of potexviruses have not been well described. In this study, we demonstrated that $\mathrm{NbCK} 2 \alpha$ colocalizes with BaMV CP at PD and is responsible for the in planta phosphorylation of $\mathrm{BaMV} \mathrm{CP}$ at amino acid S241. We also revealed that the affinity between BaMV CP and vRNA is affected by both the phosphorylation status and the type of amino acid at position 241. Cell-to-cell movement was significantly impaired by mutations of $\mathrm{CP}$, which either increase or decrease the affinity between BaMV $\mathrm{CP}$ and vRNA; this suggests that the correct timing and balance of the phosphorylation status of $\mathrm{CP}$ is critical for efficient cell-to-cell movement, through the regulation of binding and dissociation between $\mathrm{CP}$ and vRNA. Based on these observations, we propose that $\mathrm{CP}$ phosphorylation by $\mathrm{NbCK} 2 \alpha$ at S241 affects vRNA-binding ability which, in turn, controls cell-to-cell movement of BaMV.

Accumulation of viral genomic RNAs was similar in protoplasts inoculated with WT and mutants at 16 hpi but levels decreased severely in protoplasts inoculated with mutants at 24 hpi. This observation suggests that the stabilities, not the replication capabilities, of the mutant vRNAs were affected by the mutations at S241. EMSA results revealed that phosphorylation or negatively charged amino acids at position 241 of CP reduced its RNA binding affinity. In contrast, deletion of residues 240 to 242 or substitution of S241 with threonine increased the affinity of binding to vRNA. Furthermore, although these mutants retained the ability to interact with the MP TGBp1 (Fig. 8), they exhibited different movement efficiency in planta. These results suggest that the biological functions of BaMV $\mathrm{CP}$, such as vRNA binding and movement, are regulated in a phosphorylation-dependent manner.

All mutations reduced the accumulation of vRNAs and virions at later stages of infection, which may also affect cell-tocell movement. Earlier studies indicated that mutations of $\mathrm{CP}$ may influence the accumulation of vRNAs of certain potexviruses (Chapman et al. 1992; Forster et al. 1992; Lough et al. 2000). Thus, we cannot completely rule out the possibility that the defects in cell-to-cell movement result from the reduced accumulation of vRNAs. However, although all of the mutants (with the exception of S241T) exhibited similar levels of vRNA, they resulted in infection foci with significantly differ- ent sizes generated by different mutants (Figs. 4B through D and $7 \mathrm{C}$ ). These observations suggest that the mutations at S241 of CP may interfere with viral cell-to-cell movement through effects independent of the accumulation of vRNAs. As shown in this study, one possible mechanism for the fine control of BaMV cell-to-cell movement is through modulating the phosphorylation status of BaMV CP and, thus, regulating its affinity for vRNAs.

Phosphorylation of plant viral proteins reduces vRNA binding due to electric repulsion between the phosphorylated amino acids and the phosphodiester backbone of vRNAs (Ivanov et al. 2001, 2003; Stork et al. 2005; Vijayapalani et al. 2012). Consistent with these findings, we report here that phosphorylation and hyperphosphorylation (as mimicked by $\mathrm{S} 241 \mathrm{D} / \mathrm{E}$ ) of BaMV CP reduces its vRNA binding (Fig. 6). The observation that deletion of three C-terminal amino acids ( $\triangle \mathrm{TSD}$ ) of $\mathrm{CP}$ enhances its RNA binding ability may be attributed to a reduction of the negative charge (on D242). It is noteworthy that T240 of BaMV CP was also predicted to be a CK2 phosphorylation site; however, it may not be a major target of CK2. Nevertheless, minor phosphorylation of T240 by $\mathrm{NbCK} 2 \alpha$ or other kinases may also lead to a reduction of RNA-binding ability through increasing the negative charge of CP. In addition, the TGBp1 of PVX is also phosphorylated by CK2-like activity (Modena et al. 2008). Thus, CK2 may be a key factor in the fine modulation of cell-to-cell movement of potexviruses. However, our data did not exclude the possible involvement of other kinases known to be present on cell membranes or PD, such as glycogen synthase kinase 3 (Zhang et al. 2010) and calcium/calmodulin-dependent kinases II (Yang et al. 2010).

It has been postulated that potexviruses undergo cell-to-cell movement through PD as either virions or nonvirion RNP complexes consisting of TGBp1, CP, and vRNA (Cruz et al. 1998; Lough et al. 2000; Verchot-Lubicz et al. 2010). The CP is required for cell-to-cell movement of Potex-like viruses (Verchot-Lubicz 2005). A recent study showed that BaMV may undergo cell-to-cell movement in the virion form, in tight association with TGBp2- and TGBp3-based membrane complexes and TGBp1 (Chou et al. 2013). Because all the mutants in this study (except S241T) exhibited similar levels of vRNA and virions (Fig. 4; Table 1), the significant differences in cellto-cell movement (Fig. 7) indicate that BaMV is likely transported through PD as either an RNP complex or TGBps-associated virions, with the affinities between $\mathrm{CP}$ and vRNAs under the fine control of phosphorylation by host kinase $\mathrm{NbCK} 2 \alpha$. This is consistent with the findings of previous studies on the movement of PVX and BaMV (Fedorkin et al. 2000; Fedorkin et al. 2001; Lee et al. 2011).

Based on the observations in this study and the models of Verchot-Lubicz and associates (2010), we propose here a model to illustrate the regulation of cell-to-cell movement of BaMV through phosphorylation of CP S241 by CK2 (Fig. 9; the involvement of TGBp2 and TGBp3 is omitted for simplicity). Following the entrance and disassembly of BaMV in the primary infected cell, TGBp1, CP, and vRNA are generated through translation and replication; these components are assembled into RNP complexes or virions, which can then be transported to neighboring cells through PD. For WT BaMV, the $\mathrm{CP}$ may be phosphorylated by the $\mathrm{CK} 2 \alpha$ at $\mathrm{PD}$, which may facilitate the uncoating process in the secondary infected cells by reducing the affinity between $\mathrm{CP}$ and vRNAs. Thus, the vRNAs of WT BaMV would serve as templates for translation and replication, resulting in the formation of new RNP complexes or virions. Mutations that interfere with this delicate system of regulation by phosphorylation may impair the cell-to-cell movement process in different ways. The CP mutants in this 
study represent four different types of scenario that interfere with the cell-to-cell movement of BaMV (Fig. 9). i) Mutant S241A represents a scenario in which BaMV CP cannot be phosphorylated but the affinity of $\mathrm{CP}$ for vRNA is unaffected. Thus, an RNP complex consisting of TGBp1, vRNA, and CP would be assembled normally and move into neighboring cells through PD; however, they would not be phosphorylated by CK $2 \alpha$ at PD. The efficiency of the release of vRNA from the RNP complexes in the secondary infected cells would be decreased as a result, impairing further translation and replication; this would cause the observed decrease in infection foci size (Fig. 8C). ii) For mutants S241D and S241E, the negatively charged amino acid at position 241 mimics phosphorylated S241 at early stages of infection in the primary infected cells, which reduces the affinity of CP for vRNA; this interferes with the formation of stable RNP complexes or virions in the primary infected cells, resulting in a severe defect in cell-to-cell movement, reflected in the decreased size of the infection foci compared with those of S241A (Fig. 7C). iii). In mutant $\Delta \mathrm{TSD}$, the phosphorylation site was truncated but the affinity to vRNA was increased, possibly due to the removal of D242. In this mutant, formation of RNP or virions and movement through PD were not impaired. The mutant could move into neighboring cells but could not be phosphorylated by $\mathrm{CK} 2 \alpha$ at PD. The increased affinity of $\triangle \mathrm{TSD} C \mathrm{CP}$ for vRNA further interfered with the release of vRNA from the RNP complexes, resulting in significantly smaller infection foci compared with those of S241A and S241D or -E. iv) The S241T mutation (in which the phosphorylation signal is retained) increased affinity to viral genomic RNA but not subgenomic RNA; furthermore, it resulted in smaller shifts in electrophoretic mobility (Fig. 6B), indicative of the formation of a different type of RNP complex or a tightly-bound BaMV virion. The high affinity between S241T $\mathrm{CP}$ and BaMV genomic RNA may have prevented the genomic RNA from serving as templates for translation, replication, and the generation of subgenomic RNAs in the primary infected cells, and may also have inhibited the formation of appropriate RNP complexes for efficient cell-to-cell movement, thus preventing phosphorylation by CK2 $\alpha$ at PD, necessary for uncoating. The preference and tight binding of S241T $\mathrm{CP}$ to genomic RNA may have reduced the stability of the subgenomic RNAs required for the expression of CP and TGBps, thus severely decreasing infectivity. However, it should be noted that the proposed effects of various $\mathrm{CP}$ mutants on the assembly of virions or RNP complexes have not been tested by experiments; hence, the assembly aspects in the model were labeled with question marks. Further studies, such as in vitro assembly assays using mutant $\mathrm{CP}$ and vRNAs, will be conducted to verify these effects.

Together, the observations in this study have revealed an intricate regulatory mechanism for the cell-to-cell movement of BaMV. The affinity between $\mathrm{CP}$ and vRNA is regulated by the phosphorylation status of S241 at the C terminus of CP. The timing of phosphorylation by $\mathrm{CK} 2$ and balance of phosphorylated CP play important roles in regulating efficient cellto-cell movement of BaMV. The current results show the versatility of $\mathrm{CP}$ in potexviruses, and provide further insights into the infection cycles of BaMV.

\section{MATERIALS AND METHODS}

\section{Virus purification.}

The virus particles were purified from $N$. benthamiana plants infected with BaMV-S, as described previously (Lin and Chen 1991). The trans-assembled virions were purified following the same protocol, except that the final purification step involved centrifugation through a $20 \%$ sucrose cushion.

\section{LC/MS/MS.}

Purified BaMV virions or CP expressed from E. coli were subjected to trypsin digestion, followed by LC/MS/MS analysis using an ABI Qstar-XL Hybrid LC/MS/MS system (Applied Biosystems by Life Technologies, Carlsbad, CA, U.S.A.), following standard procedures (Surti et al. 2005).

\section{Plasmid construction.}

The various infectious clones used in this study were primarily based on the backbone vectors pCBG (Lin et al. 2004) and pKn (Hung et al. 2014). For protein overexpression, plasmids pET29a (Novagen, Darmstadt, Germany) and pGEX4T1 (GE Healthcare, Piscataway Township, NJ, U.S.A.) were used. The vector pUC119 (Vieira and Messing 1987) was used as a backbone for constructs used to generate RNA transcripts in vitro. BaMV 5' UTR RNA transcripts were generated from plasmids, as described (Hung et al. 2014). All BaMV CP mutants were derived from pCBG (Lin et al. 2004) via sitedirected mutagenesis with the primers listed in Supplementary Table S2, using a two-step polymerase chain reaction (PCR) method (Annamalai et al. 2003). For overexpression of WT or mutant $\mathrm{CP}$, the respective $\mathrm{CP}$ genes were amplified from the above WT and mutant pCBG-based plasmids by PCR with the forward and reverse primers. The amplified fragments were digested with $N d e I$ and EcoRI and inserted into the respective sites of pET29a (Novagen, Madison, WI, U.S.A.).

To clone and express the $C K 2 \alpha$ gene of $N$. benthamiana, total RNA was prepared from $N$. benthamiana leaf tissue, as described previously (Verwoerd et al. 1989). RNA was reverse transcribed in a total reaction volume of $20 \mu \mathrm{l}$, containing $2 \mu \mathrm{g}$ of RNA template, random hexamer primers, and $200 \mathrm{U}$ of superscript II Reverse Transcriptase (Invitrogen, Carlsbad, CA, U.S.A.), in accordance with the manufacturer's instructions. The coding region of the $C K 2 \alpha$ gene of $N$. benthamiana was amplified by PCR with specific primers ( $5^{\prime} \mathrm{CK} 2 \alpha-$ Bam HI and $3^{\prime}$ CK2 $\alpha-$ NotI), and was inserted between the BamHI and Not I sites of plasmid pGEX4T1 (GE Healthcare) after digestion with the respective enzymes. The identity of the resulting construct, pGEX4T1-CK2 $\alpha$, was confirmed by cycle sequencing.

For constructs used in BiFC, the $\mathrm{CP}$ and the $C K 2 \alpha$ gene were amplified using PCR with the appropriate forward and reverse primers, and the plasmids described above as templates. The PCR products were digested with EcoRI and BamHI and ligated into pSAT1-nEYFP-C1 and pSAT1-cEYFP-C1-B vectors (Citovsky et al. 2006), to generate the following N-terminus fusions: pSAT1-nEYFP-CP, pSAT1-nEYFP-CK2, pSAT1cEYFP-CP, and pSAT1-cEYFP-CK2. To produce the infectious clones pKn-nEYFP-CP, pKn-nEYFP-CK2, pKn-cEYFP$\mathrm{CP}$, and pKn-cEYFP-CK2, the CP and CK2 coding sequences were amplified with the appropriate primer pairs, with the aforementioned pSAT1-based vectors as templates, before being cloned into the $K p n \mathrm{I}-M l u \mathrm{I}$ sites of vector $\mathrm{pKn}$. The coding sequence of mOrange2-TMD (Thomas et al. 2008) was obtained by overlapping PCR with specific primers, and was then cloned into $\mathrm{pKn}$. For the construction of WT pKn-Cp and derived mutants, plasmid pCBG was used as a PCR template to amplify the $\mathrm{CP}$ gene with the appropriate primers pairs, and the resulting PCR products were inserted into plasmid $\mathrm{pKn}$, following restriction digestion with XhoI and KpnI or SacI. Plasmid pKBdC-G was constructed by replacing the CP coding region in plasmid $\mathrm{pKBdC}$ with that of GFP.

\section{Expression and purification of recombinant GST-CK $2 \alpha$ and wild-type and mutant CP from $E$. coli.}

To prepare CK2 $\alpha$ for subsequent assays, E. coli BL21 (DE3) was transformed with plasmid pGEX4T1-CK2 $\alpha$. Transformed bacteria were cultured at $37^{\circ} \mathrm{C}$ until reaching an optical density 
at $600 \mathrm{~nm}\left(\mathrm{OD}_{600}\right)$ of 0.6 ; at this point, protein expression was induced by addition of isopropyl $\beta$-D-1-thiogalactopyranoside to a final concentration of $0.1 \mathrm{mM}$, and the bacteria were cultured at $16^{\circ} \mathrm{C}$ for $24 \mathrm{~h}$. Bacterial cells were collected by centrifugation $(3,000 \times \mathrm{g}$ for $10 \mathrm{~min})$ and the pellet was resuspended and lysed in lysis buffer $(1 \times$ phosphate buffered saline [PBS], 5\% glycerol, 0.1\% Triton X-100, $2 \mathrm{mg} / \mathrm{ml}$ lysozyme, $1 \mathrm{mM}$ phenylmethylsulfonyl fluoride and $10 \mathrm{mM}$ dithiothreitol [DTT]). Glutathione-sepharose 4B beads (GE Healthcare) were used to purify the recombinant proteins, which were eluted from the beads with $50 \mathrm{mM}$ Tris- $\mathrm{HCl}$ (pH8.0) buffer containing $10 \mathrm{mM}$ glutathione. The eluted fractions containing GST-CK2 $\alpha$ were applied to a second heparin-sepharose column (GE Healthcare) and further purified by elution with 50 $\mathrm{mM}$ Tris- $\mathrm{HCl}$ buffer containing $2 \mathrm{M} \mathrm{NaCl}$. Recombinant $\mathrm{CP}$ and mutant derivatives were produced and purified as previously described (Hung et al. 2014).

\section{In vitro phosphorylation assays.}

The aforementioned recombinant GST-CK2 $\alpha$ was used in all in vitro phosphorylation reactions (50 ng per reaction). Assays were performed essentially as described (Ivanov et al. 2003). Each 10- $\mu$ l reaction mixture contained $25 \mathrm{mM}$ HEPES (pH 7.4), $10 \mathrm{mM} \mathrm{MgCl} 2,0.5 \mu \mathrm{l}$ of $\gamma^{32} \mathrm{P}$-ATP or -GTP (approximately $6,000 \mathrm{Ci} / \mathrm{mmol}$ ) (GE Healthcare), with $1 \mu \mathrm{g}$ of casein or purified BaMV $\mathrm{CP}$ as substrate in the presence or absence of heparin, and unlabeled GTP at the concentrations indicated in Figure $2 \mathrm{~B}$. Following incubation at $30^{\circ} \mathrm{C}$ for $30 \mathrm{~min}$, the reactions were terminated, and the proteins were separated by electrophoresis in a $12 \%$ polyacrylamide gel containing $1 \%$ SDS (SDS-PAGE) (Laemmli 1970). This SDS-PAGE was stained with Coomassie blue and then dried. The ${ }^{32} \mathrm{P}$-labeled proteins were visualized and analyzed on a BAS-2500 phosphorimager (Fujifilm, Tokyo).

\section{BiFC.}

To analyze the interactions between BaMV CP and CK2 $\alpha$, A. tumefaciens pGV3850 cells were transformed with pKnnEYFP-CP, pKn-nEYFP-CK2, pKn-cEYFP-CP, and pKncEYFP-CK2, and cultured in lysogeny broth containing ampicillin at $50 \mathrm{ppm}$, kanamycin at $10 \mathrm{ppm}$, and tetracycline at 10 ppm at $28^{\circ} \mathrm{C}$ (Giovannoni et al. 1989). For in planta assays, $A$. tumefaciens cells harboring various constructs were collected by centrifugation and resuspended in infiltration solution $(10 \mathrm{mM}$ 2-(N-morpholino)ethanesulfonic acid [pH 5.5] and $10 \mathrm{mM}$ $\mathrm{MgCl}_{2}$ ). Pairs of cultures carrying the respective $\mathrm{N}$-terminal fusion constructs were adjusted to a concentration of 0.5 at $\mathrm{OD}_{600}$, mixed, and co-infiltrated into $N$. benthamiana leaves. Inoculated leaves were observed under confocal microscopy (Olympus FV1000, Tokyo) 3 days after infiltration. For colocalization assays, two fluorescent channels were monitored separately.

\section{Detection of in planta protein interactions by immunoprecipitation.}

To verify the interactions between BaMV CP and TGBp1, A. tumefaciens cells were transformed with various $\mathrm{pKn}$-based constructs encoding WT and mutant $\mathrm{CP}$, then used to infiltrate into $N$. benthamiana for in planta assays, as described previously (Hung et al. 2014). Immunoprecipitation experiments were performed essentially as described (Saez et al. 2008). Briefly, whole proteins were extracted from $N$. benthamiana leaves co-infiltrated with various $\mathrm{pKn}-\mathrm{CP}$ and $\mathrm{pKn}-\mathrm{TGBp} 1$ constructs at $2 \mathrm{dpi}$, with three volumes of PBS containing 1 $\mathrm{mM}$ EDTA, $0.05 \%$ Triton X-100, and a protease inhibitor cocktail (Roche, Indianapolis, IN, U.S.A.). To detect the interactions between BaMV CP and CK2 $\alpha$ in $N$. benthamiana and $C$. quinoa, the leaves of plants were mechanically inoculated with $400 \mathrm{ng}$ of virions of BaMV. The membrane fraction (P30) was extracted from leaves inoculated with virus at $7 \mathrm{dpi}$, as described previously (Lee et al. 2011). Following measurement of protein concentration using Bradford reagent (SigmaAldrich, St. Louis), $500 \mu \mathrm{g}$ of total protein or membrane protein (P30) was incubated with $2 \mu \mathrm{l}$ of TGBp1- or CK2 $\alpha$-specific antibody $\left(250 \times\right.$ dilution) for $4 \mathrm{~h}$ at $4{ }^{\circ} \mathrm{C}$. Proteins interacting with TGBp1 or CK2 $\alpha$ were precipitated by the addition of 20 $\mu \mathrm{l}$ of Protein A beads (GE Healthcare), followed by incubation for $1 \mathrm{~h}$.

\section{Protoplast assays.}

Protoplasts from $N$. benthamiana were prepared as described previously (Cheng and Tsai 1999). For each assay, approximately $2 \times 10^{5}$ protoplasts were inoculated with $10 \mu \mathrm{g}$ of plasmid DNA. Total RNA and protein were extracted from inoculated protoplasts and plants and analyzed by Northern and Western blots, respectively.

\section{In vitro transcription and EMSA.}

To generate radiolabeled RNA probes for EMSA, plasmid templates were linearized with EcoRI and subjected to in vitro transcription, as described (Lin et al. 1996). RNA transcripts were recovered from 5\% PAGE in $0.5 \times$ Tris-borate-EDTA (TBE). For EMSA, various CP were incubated with $1 \mathrm{fmol}$ of radiolabeled RNA transcript corresponding to BaMV 5' UTR nucleotides 1 to 93 . The reaction mixtures were kept at room temperature for $15 \mathrm{~min}$ in a binding buffer consisting of 20 $\mathrm{mM}$ Tris- $\mathrm{HCl}(\mathrm{pH} 8.0), 3 \mathrm{mM} \mathrm{MgCl}, 10 \mathrm{mM} \mathrm{KCl}, 2 \mathrm{mM}$ DTT, $100 \mathrm{mM} \mathrm{NaCl}, 4 \%$ glycerol, and $5 \mathrm{U}$ of RNase inhibitors (TaKaRa, Otsu, Shiga, Japan). The reaction products were separated by electrophoresis in a $1 \%$ agarose gel in $0.5 \times$ TBE. Signals were visualized with a BAS-2500 phosphorimager and quantified using MultiGauge software (Fujifilm). The binding coefficients were calculated from three independent EMSA replicates using the Hill equation (Ryder et al. 2008).

\section{TEM and observation of GFP fluorescence.}

TEM and fluorescence microscopy were employed as previously described (Hung et al. 2014), in order to examine virion morphology and cell-to-cell movement via GFP fluorescence.

\section{ACKNOWLEDGMENTS}

We thank S. B. GeIvin at Purdue University for providing us with the BiFC plasmids. This research was supported by the Ministry of Science and Technology, Taiwan (grants NSC101-2321-B-005-006 and NSC1012313-B-005-036-MY3) and Aim for the Top University Project of the National Chung Hsing University by the Ministry of Education, Taiwan.

\section{LITERATURE CITED}

Alcaide-Loridan, C., and Jupin, I. 2012. Ubiquitin and plant viruses, let's play together! Plant Physiol. 160:72-82.

Allende, J. E., and Allende, C. C. 1995. Protein kinases. 4. Protein kinase CK2: An enzyme with multiple substrates and a puzzling regulation. FASEB (Fed. Am. Soc. Exp. Biol.) J. 9:313-323.

Annamalai, P., Hsu, Y. H., Liu, Y. P., Tsai, C. H., and Lin, N.-S. 2003. Structural and mutational analyses of cis-acting sequences in the $5^{\prime}$ untranslated region of satellite RNA of bamboo mosaic potexvirus. Virology 311:229-239.

Atabekov, J. G., Rodionova, N. P., Karpova, O. V., Kozlovsky, S. V., Novikov, V. K., and Arkhipenko, M. V. 2001. Translational activation of encapsidated Potato virus $X$ RNA by coat protein phosphorylation. Virology 286:466-474.

Barajas, D., and Nagy, P. D. 2010. Ubiquitination of tombusvirus p33 replication protein plays a role in virus replication and binding to the host Vps23p ESCRT protein. Virology 397:358-368.

Blom, N., Sicheritz-Ponten, T., Gupta, R., Gammeltoft, S., and Brunak, S. 2004. Prediction of post-translational glycosylation and phosphoryla- 
tion of proteins from the amino acid sequence. Proteomics 4:16331649

Bombarely, A., Menda, N., Tecle, I. Y., Buels, R. M., Strickler, S., FischerYork, T., Pujar, A., Leto, J., Gosselin, J., and Mueller, L. A. 2011. The Sol Genomics Network (solgenomics.net): Growing tomatoes using Perl. Nucleic Acids Res. 39:D1149-D1155.

Bond, A. E., Row, P. E., and Dudley, E. 2011. Post-translation modification of proteins; methodologies and applications in plant sciences. Phytochemistry 72:975-996.

Champagne, J., Laliberte-Gagne, M. E., and Leclerc, D. 2007. Phosphorylation of the termini of Cauliflower mosaic virus precapsid protein is important for productive infection. Mol. Plant-Microbe Interact. 20:648-658

Chapdelaine, Y., Kirk, D., Karsies, A., Hohn, T., and Leclerc, D. 2002. Mutation of capsid protein phosphorylation sites abolishes Cauliflower mosaic virus infectivity. J. Virol. 76:11748-11752.

Chapman, S., Hills, G., Watts, J., and Baulcombe, D. 1992. Mutational analysis of the coat protein gene of potato virus X: Effects on virion morphology and viral pathogenicity. Virology 191:223-230.

Cheng, C. P., and Tsai, C. H. 1999. Structural and functional analysis of the $3^{\prime}$ untranslated region of bamboo mosaic potexvirus genomic RNA. J. Mol. Biol. 288:555-565.

Chou, Y. L., Hung, Y. J., Tseng, Y. H., Hsu, H. T., Yang, J. Y., Wung, C. H., Lin, N.-S., Meng, M., Hsu, Y. H., and Chang, B. Y. 2013. The stable association of virion with the triple-gene-block protein 3-based complex of Bamboo mosaic virus. PLoS Pathog. 9:e1003405.

Chowda-Reddy, R. V., Achenjang, F., Felton, C., Etarock, M. T., Anangfac, M. T., Nugent, P., and Fondong, V. N. 2008. Role of a geminivirus AV2 protein putative protein kinase $\mathrm{C}$ motif on subcellular localization and pathogenicity. Virus Res. 135:115-124.

Citovsky, V., McLean, B. G., Zupan, J. R., and Zambryski, P. 1993. Phosphorylation of tobacco mosaic virus cell-to-cell movement protein by a developmentally regulated plant cell wall-associated protein kinase. Genes Dev. 7:904-910.

Citovsky, V., Lee, L. Y., Vyas, S., Glick, E., Chen, M. H., Vainstein, A., Gafni, Y., Gelvin, S. B., and Tzfira, T. 2006. Subcellular localization of interacting proteins by bimolecular fluorescence complementation in planta. J. Mol. Biol. 362:1120-1131.

Cohen, P. 2000. The regulation of protein function by multisite phosphorylation - a 25 year update. Trends Biochem. Sci. 25:596-601.

Cruz, S. S., Roberts, A. G., Prior, D. A., Chapman, S., and Oparka, K. J. 1998. Cell-to-cell and phloem-mediated transport of potato virus X. The role of virions. Plant Cell 10:495-510.

Dean, A. M., and Koshland, D. E., Jr. 1990. Electrostatic and steric contributions to regulation at the active site of isocitrate dehydrogenase. Science 249:1044-1046.

Faust, M., and Montenarh, M. 2000. Subcellular localization of protein kinase CK2. A key to its function? Cell Tissue Res. 301:329-340.

Fedorkin, O., Solovyev, A., Yelina, N., Zamyatnin, A., Jr., Zinovkin, R., Makinen, K., Schiemann, J., and Yu Morozov, S. 2001. Cell-to-cell movement of Potato virus $X$ involves distinct functions of the coat protein. J. Gen. Virol. 82:449-458.

Fedorkin, O. N., Merits, A., Lucchesi, J., Solovyev, A. G., Saarma, M. Morozov, S. Y., and Makinen, K. 2000. Complementation of the movement-deficient mutations in Potato virus $X$ : Potyvirus coat protein mediates cell-to-cell trafficking of C-terminal truncation but not deletion mutant of potexvirus coat protein. Virology 270:31-42.

Florentino, L. H., Santos, A. A., Fontenelle, M. R., Pinheiro, G. L., Zerbini, F. M., Baracat-Pereira, M. C., and Fontes, E. P. 2006. A PERKlike receptor kinase interacts with the geminivirus nuclear shuttle protein and potentiates viral infection. J. Virol. 80:6648-6656.

Forster, R. L., Beck, D. L., Guilford, P. J., Voot, D. M., Van Dolleweerd, C. J., and Andersen, M. T. 1992. The coat protein of white clover mosaic potexvirus has a role in facilitating cell-to-cell transport in plants. Virology 191:480-484

Giovannoni, J. J., DellaPenna, D., Bennett, A. B., and Fischer, R. L. 1989. Expression of a chimeric polygalacturonase gene in transgenic rin (ripening inhibitor) tomato fruit results in polyuronide degradation but not fruit softening. Plant Cell 1:53-63.

Haley, A., Hunter, T., Kiberstis, P., and Zimmern, D. 1995. Multiple serine phosphorylation sites on the $30 \mathrm{kDa}$ TMV cell-to-cell movement protein synthesized in tobacco protoplasts. Plant J. 8:715-724.

Hathaway, G. M., Lubben, T. H., and Traugh, J. A. 1980. Inhibition of casein kinase II by heparin. J. Biol. Chem. 255:8038-8041

Hung, C. J., Hu, C. C., Lin, N.-S., Lee, Y. C., Meng, M., Tsai, C. H., and Hsu, Y. H. 2014. Two key arginine residues in the coat protein of Bamboo mosaic virus differentially affect the accumulation of viral genomic and subgenomic RNAs. Mol. Plant Pathol. 15:196-210.

Ivanov, K. I., Puustinen, P., Merits, A., Saarma, M., and Makinen, K. 2001. Phosphorylation down-regulates the RNA binding function of the coat protein of Potato virus A. J. Biol. Chem. 276:13530-13540.

Ivanov, K. I., Puustinen, P., Gabrenaite, R., Vihinen, H., Ronnstrand, L., Valmu, L., Kalkkinen, N., and Makinen, K. 2003. Phosphorylation of the potyvirus capsid protein by protein kinase CK2 and its relevance for virus infection. Plant Cell 15:2124-2139.

Jakubiec, A., and Jupin, I. 2007. Regulation of positive-strand RNA virus replication: The emerging role of phosphorylation. Virus Res. 129:7379

Jakubiec, A., Tournier, V., Drugeon, G., Pflieger, S., Camborde, L., Vinh, J., Hericourt, F., Redeker, V., and Jupin, I. 2006. Phosphorylation of viral RNA-dependent RNA polymerase and its role in replication of a plus-strand RNA virus. J. Biol. Chem. 281:21236-21249.

Karger, E. M., Frolova, O. Y., Fedorova, N. V., Baratova, L. A., Ovchinnikova, T. V., Susi, P., Makinen, K., Ronnstrand, L., Dorokhov, Y. L., and Atabekov, J. G. 2003. Dysfunctionality of a Tobacco mosaic virus movement protein mutant mimicking threonine 104 phosphorylation. J. Gen. Virol. 84:727-732.

Karpova, O. V., Rodionova, N. P., Ivanov, K. I., Kozlovsky, S. V., Dorokhov, Y. L., and Atabekov, J. G. 1999. Phosphorylation of Tobacco mosaic virus movement protein abolishes its translation repressing ability. Virology 261:20-24.

Kawakami, S., Padgett, H. S., Hosokawa, D., Okada, Y., Beachy, R. N., and Watanabe, Y. 1999. Phosphorylation and/or presence of serine 37 in the movement protein of tomato mosaic tobamovirus is essential for intracellular localization and stability in vivo. J. Virol. 73:6831-6840.

Kawakami, S., Hori, K., Hosokawa, D., Okada, Y., and Watanabe, Y. 2003. Defective tobamovirus movement protein lacking wild-type phosphorylation sites can be complemented by substitutions found in revertants. J. Virol. 77:1452-1461.

Kleinow, T., Nischang, M., Beck, A., Kratzer, U., Tanwir, F., Preiss, W., Kepp, G., and Jeske, H. 2009. Three C-terminal phosphorylation sites in the Abutilon mosaic virus movement protein affect symptom development and viral DNA accumulation. Virology 390:89-101.

Laemmli, U. K. 1970. Cleavage of structural proteins during the assembly of the head of bacteriophage T4. Nature 227:680-685.

Lan, P., Yeh, W. B., Tsai, C. W., and Lin, N.-S. 2010. A unique glycinerich motif at the N-terminal region of Bamboo mosaic virus coat protein is required for symptom expression. Mol. Plant-Microbe Interact. 23:903-914.

Lee, C. C., Ho, Y. N., Hu, R. H., Yen, Y. T., Wang, Z. C., Lee, Y. C., Hsu, Y. H., and Meng, M. 2011. The interaction between Bamboo mosaic virus replication protein and coat protein is critical for virus movement in plant hosts. J. Virol. 85:12022-12031.

Lee, J. Y., and Lucas, W. J. 2001. Phosphorylation of viral movement proteins-Regulation of cell-to-cell trafficking. Trends Microbiol. 9:5-8.

Lewsey, M., Surette, M., Robertson, F. C., Ziebell, H., Choi, S. H., Ryu, K. H., Canto, T., Palukaitis, P., Payne, T., Walsh, J. A., and Carr, J. P. 2009. The role of the Cucumber mosaic virus $2 \mathrm{~b}$ protein in viral movement and symptom induction. Mol. Plant-Microbe Interact. 22:642-654.

Lin, M. K., Chang, B. Y., Liao, J. T., Lin, N.-S., and Hsu, Y. H. 2004 Arg-16 and Arg-21 in the N-terminal region of the triple-gene-block protein 1 of Bamboo mosaic virus are essential for virus movement. J. Gen. Virol. 85:251-259.

Lin, M. K., Hu, C. C., Lin, N.-S., Chang, B. Y., and Hsu, Y. H. 2006. Movement of potexviruses requires species-specific interactions among the cognate triple gene block proteins, as revealed by a trans-complementation assay based on the Bamboo mosaic virus satellite RNAmediated expression system. J. Gen. Virol. 87:1357-1367.

Lin, M. T., Kitajima, E. W., Cupertino, F. P., and Costa, C. L. 1977. Partial purification and some properties of bamboo mosaic virus. Phytopathology 67:1439-1443.

Lin, N.-S., and Chen, C.-C. 1991. Association of bamboo mosaic virus (BoMV) and BoMV-specific electron-dense crystalline bodies with chloroplasts. Phytopathology 81:1551-1555.

Lin, N.-S., Lin, F. Z., Huang, T. Y., and Hsu, Y. H. 1992. Genome properties of bamboo mosaic virus. Phytopathology 82:731-734.

Lin, N.-S., Lin, B. Y., Lo, N. W., Hu, C. C., Chow, T. Y., and Hsu, Y. H. 1994. Nucleotide sequence of the genomic RNA of bamboo mosaic potexvirus. J. Gen. Virol. 75 2513-2518.

Lin, N.-S., Lee, Y. S., Lin, B. Y., Lee, C. W., and Hsu, Y. H. 1996. The open reading frame of bamboo mosaic potexvirus satellite RNA is not essential for its replication and can be replaced with a bacterial gene. Proc. Natl. Acad. Sci. U.S.A. 93:3138-3142.

Link, K., Vogel, F., and Sonnewald, U. 2011. PD Trafficking of Potato leaf roll virus movement protein in Arabidopsis depends on site-specific protein phosphorylation. Front. Plant Sci. 2:18.

Litchfield, D. W. 2003. Protein kinase CK2: Structure, regulation and role in cellular decisions of life and death. Biochem. J. 369:1-15.

Lough, T. J., Netzler, N. E., Emerson, S. J., Sutherland, P., Carr, F., Beck, D. L., Lucas, W. J., and Forster, R. L. 2000. Cell-to-cell movement of 
potexviruses: Evidence for a ribonucleoprotein complex involving the coat protein and first triple gene block protein. Mol. Plant-Microbe Interact. 13:962-974.

Lucas, W. J. 2006. Plant viral movement proteins: Agents for cell-to-cell trafficking of viral genomes. Virology 344:169-184.

Mathur, C., Jimsheena, V. K., Banerjee, S., Makinen, K., Gowda, L. R., and Savithri, H. S. 2012. Functional regulation of PVBV Nuclear Inclusion protein-a protease activity upon interaction with Viral Protein genome-linked and phosphorylation. Virology 422:254-264.

Meggio, F., and Pinna, L. A. 2003. One-thousand-and-one substrates of protein kinase CK2? FASEB (Fed. Am. Soc. Exp. Biol.) J. 17:349-368.

Modena, N. A., Zelada, A. M., Conte, F., and Mentaberry, A. 2008. Phosphorylation of the TGBp1 movement protein of Potato virus $X$ by a Nicotiana tabacum CK2-like activity. Virus Res. 137:16-23.

Perez Jde, J., Udeshi, N. D., Shabanowitz, J., Ciordia, S., Juarez, S., Scott, C. L., Olszewski, N. E., Hunt, D. F., and Garcia, J. A. 2013. O-GlcNAc modification of the coat protein of the potyvirus Plum pox virus enhances viral infection. Virology 442:122-131.

Prabakaran, S., Lippens, G., Steen, H., and Gunawardena, J. 2012. Posttranslational modification: Nature's escape from genetic imprisonment and the basis for dynamic information encoding. Wiley Interdiscip. Rev. Syst. Biol. Med. 4:565-583.

Rodriguez, F., Allende, C. C., and Allende, J. E. 2005. Protein kinase casein kinase 2 holoenzyme produced ectopically in human cells can be exported to the external side of the cellular membrane. Proc. Natl. Acad. Sci. U.S.A. 102:4718-4723.

Ryder, S. P., Recht, M. I., and Williamson, J. R. 2008. Quantitative analysis of protein-RNA interactions by gel mobility shift. Methods Mol. Biol. 488:99-115.

Saez, A., Rodrigues, A., Santiago, J., Rubio, S., and Rodriguez, P. L. 2008. HAB1-SWI3B interaction reveals a link between abscisic acid signaling and putative SWI/SNF chromatin-remodeling complexes in Arabidopsis. Plant Cell 20:2972-2988.

Salinas, P., Fuentes, D., Vidal, E., Jordana, X., Echeverria, M., and Holuigue, L. 2006. An extensive survey of CK2 alpha and beta subunits in Arabidopsis: Multiple isoforms exhibit differential subcellular localization. Plant Cell Physiol. 47:1295-1308.

Samuilova, O., Santala, J., and Valkonen, J. P. 2013. Tyrosine phosphorylation of the triple gene block protein 3 regulates cell-to-cell movement and protein interactions of Potato mop-top virus. J. Virol. 87:4313-4321.

Shapka, N., Stork, J., and Nagy, P. D. 2005. Phosphorylation of the p33 replication protein of Cucumber necrosis tombusvirus adjacent to the RNA binding site affects viral RNA replication. Virology 343:65-78.

Stork, J., Panaviene, Z., and Nagy, P. D. 2005. Inhibition of in vitro RNA binding and replicase activity by phosphorylation of the p33 replication protein of Cucumber necrosis tombusvirus. Virology 343:79-92.

Surti, T. S., Huang, L., Jan, Y. N., Jan, L. Y., and Cooper, E. C. 2005. Identification by mass spectrometry and functional characterization of two phosphorylation sites of KCNQ2/KCNQ3 channels. Proc. Natl. Acad. Sci. U.S.A. 102:17828-17833.

Thomas, C. L., Bayer, E. M., Ritzenthaler, C., Fernandez-Calvino, L., and Maule, A. J. 2008. Specific targeting of a plasmodesmal protein affecting cell-to-cell communication. PLoS Biol. 6:e7.

Trutnyeva, K., Bachmaier, R., and Waigmann, E. 2005. Mimicking carboxyterminal phosphorylation differentially effects subcellular distribution and cell-to-cell movement of Tobacco mosaic virus movement protein. Virology 332:563-577.

Tseng, Y. H., Hsu, H. T., Chou, Y. L., Hu, C. C., Lin, N.-S., Hsu, Y. H., and Chang, B. Y. 2009. The two conserved cysteine residues of the triple gene block protein 2 are critical for both cell-to-cell and systemic movement of Bamboo mosaic virus. Mol. Plant-Microbe Interact. $22: 1379-1388$

Verchot-Lubicz, J. 2005. A new cell-to-cell transport model for Potexviruses. Mol. Plant-Microbe Interact. 18:283-290.

Verchot-Lubicz, J., Ye, C. M., and Bamunusinghe, D. 2007. Molecular biology of potexviruses: Recent advances. J. Gen. Virol. 88:1643-1655.

Verchot-Lubicz, J., Torrance, L., Solovyev, A. G., Morozov, S. Y., Jackson, A. O., and Gilmer, D. 2010. Varied movement strategies employed by triple gene block-encoding viruses. Mol. Plant-Microbe Interact 23:1231-1247.

Verwoerd, T. C., Dekker, B. M., and Hoekema, A. 1989. A small-scale procedure for the rapid isolation of plant RNAs. Nucleic Acids Res. $17: 2362$.

Vieira, J., and Messing, J. 1987. Production of single-stranded plasmid DNA. Methods Enzymol. 153:3-11.

Vijayapalani, P., Chen, J. C., Liou, M. R., Chen, H. C., Hsu, Y. H., and Lin, N.-S. 2012. Phosphorylation of Bamboo mosaic virus satellite RNA (satBaMV)-encoded protein P20 downregulates the formation of satBaMV-P20 ribonucleoprotein complex. Nucleic Acids Res. 40:638649.

Waigmann, E., Chen, M. H., Bachmaier, R., Ghoshroy, S., and Citovsky, V. 2000. Regulation of plasmodesmal transport by phosphorylation of Tobacco mosaic virus cell-to-cell movement protein. EMBO (Eur. Mol. Biol. Organ.) J. 19:4875-4884.

Wu, C. H., Lee, S. C., and Wang, C. W. 2011. Viral protein targeting to the cortical endoplasmic reticulum is required for cell-cell spreading in plants. J. Cell Biol. 193:521-535.

Xiong, R., and Wang, A. 2013. SCE1, the SUMO-conjugating enzyme in plants that interacts with $\mathrm{NIb}$, the RNA-dependent RNA polymerase of Turnip mosaic virus, is required for viral infection. J. Virol. 87:47044715 .

Yang, C. C., Liu, J. S., Lin, C. P., and Lin, N.-S. 1997. Nucleotide sequence and phylogenetic analysis of a bamboo mosaic potexvirus isolate from common bamboo (Bambusa vulgaris McClure). Bot. Bull. Acad. Sin. 38:77-84.

Yang, C. D., Liao, J. T., Lai, C. Y., Jong, M. H., Liang, C. M., Lin, Y. L., Lin, N.-S., Hsu, Y. H., and Liang, S. M. 2007. Induction of protective immunity in swine by recombinant Bamboo mosaic virus expressing foot-and-mouth disease virus epitopes. BMC Biotechnol. 7:62.

Yang, L., Ji, W., Zhu, Y., Gao, P., Li, Y., Cai, H., Bai, X., and Guo, D. 2010. GsCBRLK, a calcium/calmodulin-binding receptor-like kinase, is a positive regulator of plant tolerance to salt and ABA stress. J. Exp. Bot. 61:2519-2533.

Zayakina, O., Arkhipenko, M., Kozlovsky, S., Nikitin, N., Smirnov, A., Susi, P., Rodionova, N., Karpova, O., and Atabekov, J. 2008. Mutagenic analysis of Potato virus $X$ movement protein (TGBp1) and the coat protein $(\mathrm{CP})$ : In vitro TGBp1-CP binding and viral RNA translation activation. Mol. Plant Pathol. 9:37-44.

Zhang, C., Zhao, H., Liu, Y., Li, Q., Liu, X., Tan, H., Yuan, C., and Dong, Y. 2010. Isolation and characterization of a novel glycogen synthase kinase-3 gene, GmGSK, in Glycine max L. that enhances abiotic stress tolerance in Saccharomyces cerevisiae. Biotechnol. Lett. 32:861-866.

\section{AUTHOR-RECOMMENDED INTERNET RESOURCE}

Center for Biological Sequence Analysis NetPhosK 1.0 server: www.cbs.dtu.dk/services/NetPhosK 